\title{
Neuronal $a_{2} \delta$ proteins and brain disorders
}

\section{Cornelia Ablinger $^{1}$ (D) $\cdot$ Stefanie M. Geisler ${ }^{2}$ (D) Ruslan I. Stanika $^{3}$ (D) $\cdot$ Christian T. Klein $^{4}$ (D) $\cdot$ Gerald J. Obermair ${ }^{1,3}$ (D)}

Received: 24 April 2020 / Revised: 8 June 2020 / Accepted: 12 June 2020 / Published online: 30 June 2020

(C) The Author(s) 2020

\begin{abstract}
$\alpha_{2} \delta$ proteins are membrane-anchored extracellular glycoproteins which are abundantly expressed in the brain and the peripheral nervous system. They serve as regulatory subunits of voltage-gated calcium channels and, particularly in nerve cells, regulate presynaptic and postsynaptic functions independently from their role as channel subunits. $\alpha_{2} \delta$ proteins are the targets of the widely prescribed anti-epileptic and anti-allodynic drugs gabapentin and pregabalin, particularly for the treatment of neuropathic pain conditions. Recently, the human genes (CACNA2D1-4) encoding for the four known $\alpha_{2} \delta$ proteins (isoforms $\alpha_{2} \delta-1$ to $\alpha_{2} \delta-4$ ) have been linked to a large variety of neurological and neuropsychiatric disorders including epilepsy, autism spectrum disorders, bipolar disorders, schizophrenia, and depressive disorders. Here, we provide an overview of the hitherto identified disease associations of all known $\alpha_{2} \delta$ genes, hypothesize on the pathophysiological mechanisms considering their known physiological roles, and discuss the most immanent future research questions. Elucidating their specific physiological and pathophysiological mechanisms may open the way for developing entirely novel therapeutic paradigms for treating brain disorders.
\end{abstract}

Keywords Neurological disease $\cdot$ Autism $\cdot$ Schizophrenia $\cdot$ Epilepsy $\cdot$ Synapses $\cdot$ CACNA2D1-4

\section{Introduction}

$\alpha_{2} \delta$ proteins are membrane-anchored extracellular glycoproteins which have initially been identified as subunits of voltage-gated calcium channels (VGCCs). An increasing number of studies, however, suggest functions independent of the calcium channel complex. $\alpha_{2} \delta$ proteins are the targets of the widely prescribed anti-epileptic and anti-allodynic drugs gabapentin and pregabalin and have been linked to a large variety of diseases. In this review, we provide an overview of the known and putative associations of $\alpha_{2} \delta$ genes and

This article is published as part of the Special Issue on Channelopathies: from mutation to diseases

Gerald J. Obermair

Gerald.Obermair@kl.ac.at

1 Institute of Physiology, Medical University Innsbruck, 6020 Innsbruck, Austria

2 Department of Pharmacology and Toxicology, University of Innsbruck, 6020 Innsbruck, Austria

3 Division Physiology, Karl Landsteiner University of Health Sciences, 3500 Krems, Austria

4 Department of Life Sciences, IMC University of Applied Sciences, 3500 Krems, Austria proteins with human neurological disorders. Furthermore, we discuss channel-dependent and channel-independent mechanisms of potential relevance for the respective pathophysiological mechanisms.

\section{$a_{2} \delta$ genes and proteins}

In the human genome, four genes (CACNA2D1-4) code for four $\alpha_{2} \delta$ proteins $\left(\alpha_{2} \delta-1\right.$ to $\left.\alpha_{2} \delta-4\right)$, which give rise to multiple transcripts as the result of alternative splicing [31, 60]. The genes contain 38 or 39 exons, and the distribution of exons over the gene is similar between $\alpha_{2} \delta-1$ and $\alpha_{2} \delta-2$ (Fig. 1) but considerably different in $\alpha_{2} \delta-3$ and $\alpha_{2} \delta-4$ (Fig. 2). Mature $\alpha_{2} \delta$ proteins lack the co-translationally cleaved $\mathrm{N}$-terminal signal peptide and are highly glycosylated extracellular proteins of 140 to $170 \mathrm{kDa}$. They are posttranslationally cleaved into $\alpha_{2}$ and $\delta$ moieties, which are covalently bound through disulfide bonds [13, 27, 126]. $\alpha_{2} \delta$ proteins are most likely attached to the plasma membrane via glycosylphosphatidylinositol (GPI) anchors [26]; alternatively, however, the $\delta$ polypeptide chain may form a transmembrane $\alpha$-helix [91]. Even though all $\alpha_{2} \delta$ subunits contain well-known protein domains including a von Willebrand factor A (VWA) domain, the detailed structure is still under debate. As of today, the most precise estimation of $\alpha_{2} \delta$ protein structure is based on a cryogenic electron microscopy (cryo-EM) study of 
a

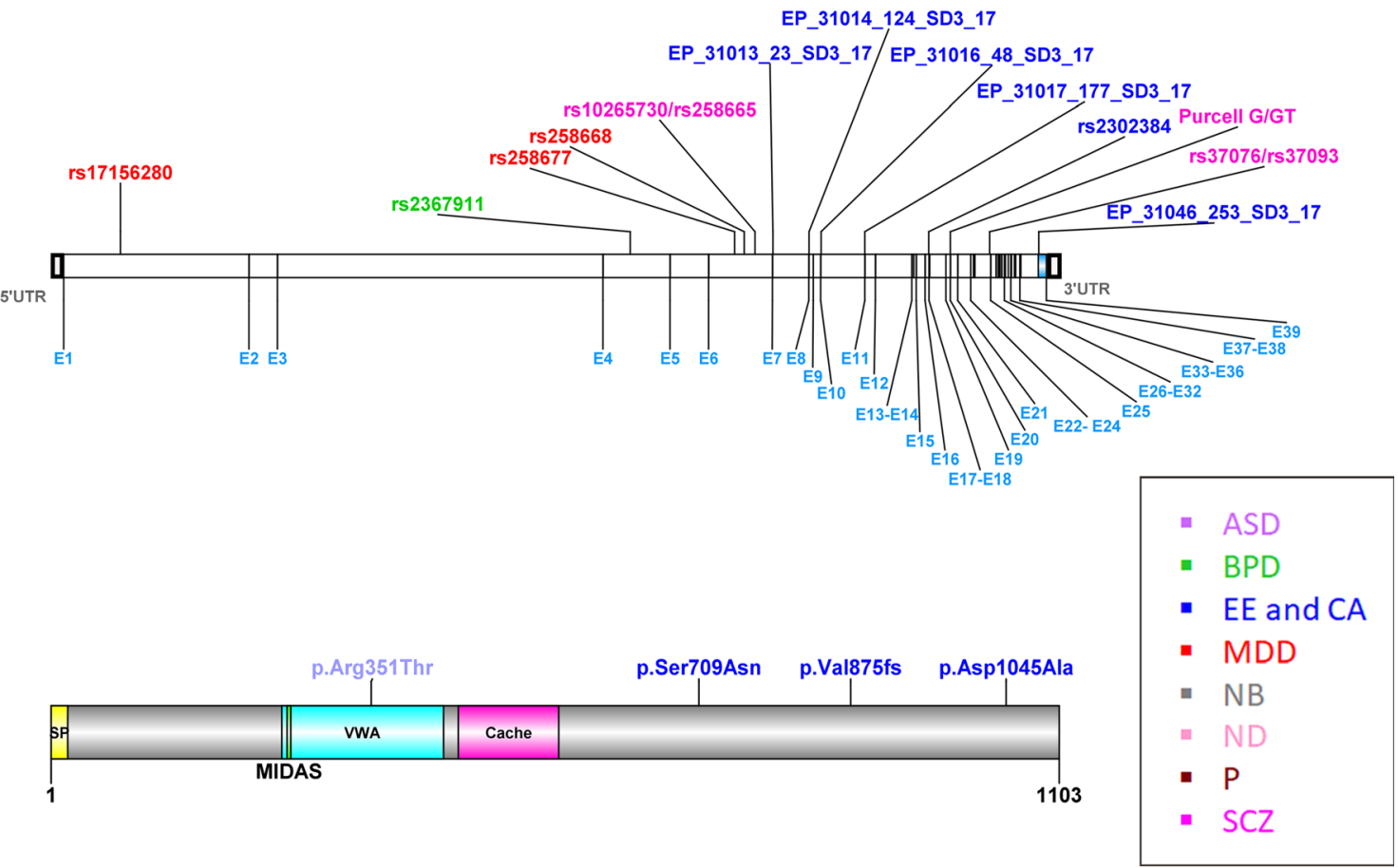

b

CACNA2D1

(497333bp)

$h a_{2} \delta-1$

EE and CA

MDD

NB

ND

- P

- SCZ

CACNA2D2

(140795bp)

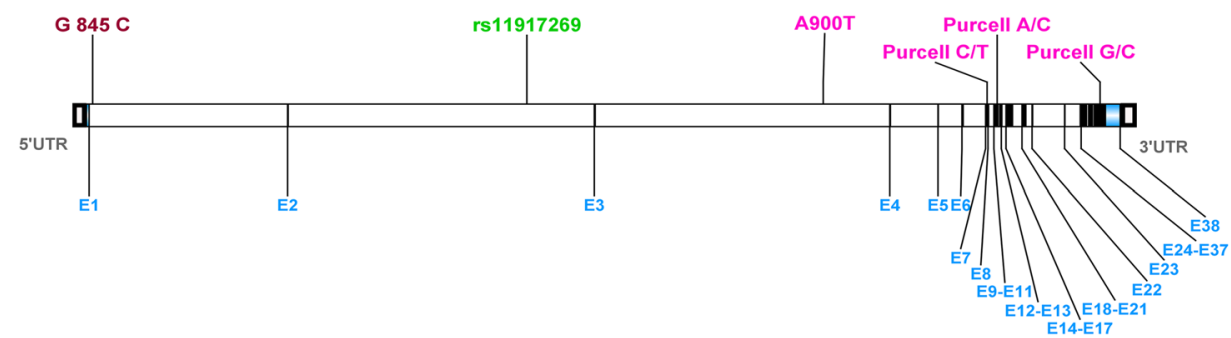

$\mathrm{ha}_{2} \delta-2$

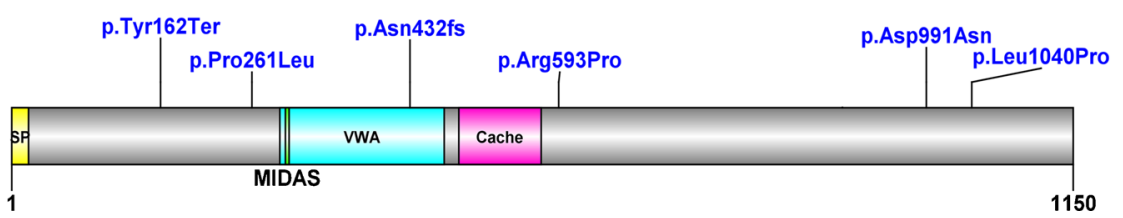

Fig. 1 Reference maps of predicted human $\alpha_{2} \delta-1$ and $\alpha_{2} \delta-2$ neuronal disease mutations and SNPs. Models of CACNA2D1 and CACNA2D2 genes (upper panels in a and $\mathbf{b}$ ) and protein structures (lower panels in a and b), including exon positions (light blue) and protein domains, are based on Ensembl and UniProt databases (ENST00000356253.9/ P54289; ENST00000266039.7/Q9NY47). Previously published potentially disease-associated SNPs and disease mutations are indicated (see text for references). The protein structure of all $\alpha_{2} \delta$ proteins is highly

conserved sharing an N-terminal signal peptide (SP, yellow), a von Willebrand factor A domain (VWA, turquois), a cache domain (magenta), and a MIDAS site (green) (see also Fig. 2). ASD (violet), autism spectrum disorders; BPD (green), bipolar disorder; CA (blue), cerebellar atrophy; EE (blue), epileptic encephalopathy; MDD (red), major depressive disorder; NB (gray), night blindness; ND (nude), nicotine dependence; P (bordeaux), pain; SCZ (magenta), schizophrenia

the $\alpha_{2} \delta-1$ isoform complexed with the skeletal muscle calcium channel [126]. $\alpha_{2} \delta$ proteins undergo multiple posttranslational modifications, which make them rather unique, considering that proteolytic processing is a rare feature in VWA-containing

proteins. Generally, VWA domains by means of their metal ion-dependent adhesion site (MIDAS) are involved in proteinprotein interactions such as extracellular matrix-cell adhesion proteins [124]. While all $\alpha_{2} \delta$ subunits contain a MIDAS motif, 
a
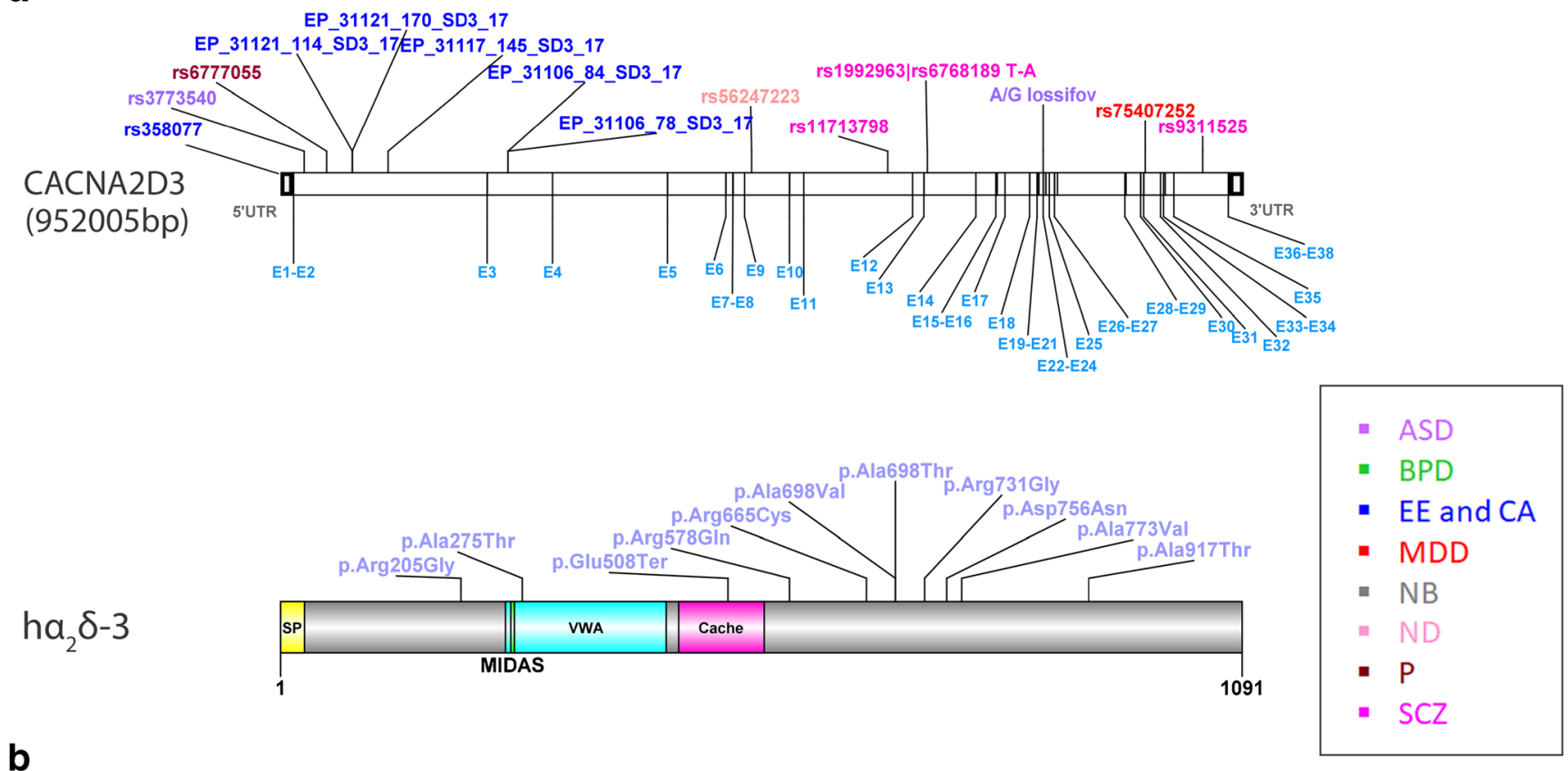

b

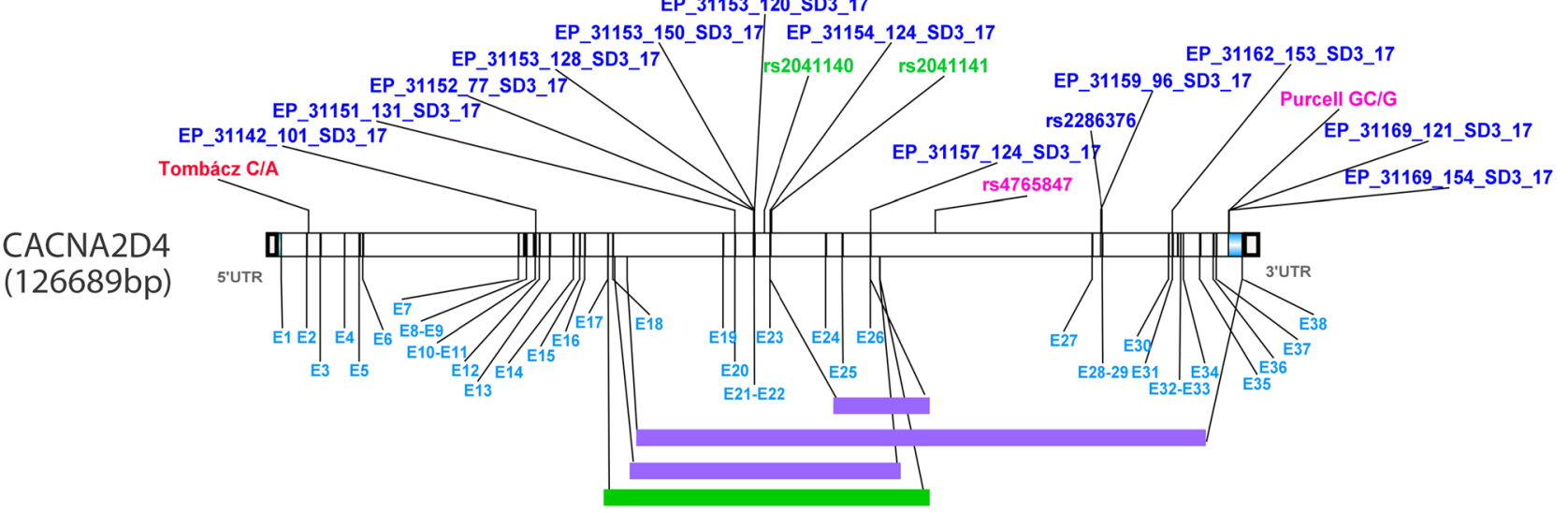

$\mathrm{ha}_{2} \delta-4$

p.Arg707His p.Tyr802Ter

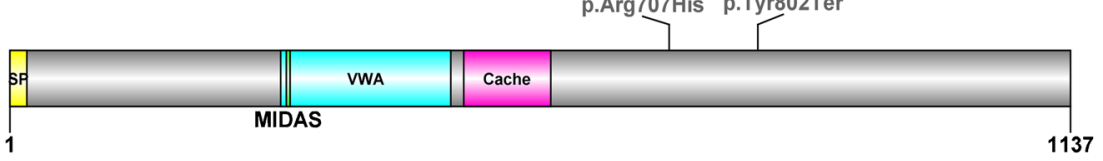

Fig. 2 Reference maps of predicted human $\alpha_{2} \delta-3$ and $\alpha_{2} \delta-4$ neuronal disease mutations and SNPs. Models of CACNA2D3 and CACNA2D4 genes (upper panels in $\mathbf{a}$ and $\mathbf{b}$ ) and protein structures (lower panels in $\mathbf{a}$ and b), including exon positions (light blue) and protein domains, are based on Ensembl and UniProt databases (ENST00000288197.9/ Q8IZS8; ENST00000382722.10/Q7Z3S7). Previously published potentially disease-associated SNPs and disease mutations are indicated (see text for references). Large genomic deletions of CACNA2D4 (b)

only $\alpha_{2} \delta-1$ and $\alpha_{2} \delta-2$ incorporate the "perfect" MIDAS motif in which the presence of all five coordinating amino acids is predicted $[14,124]$. This implies that structural rearrangement of the protein complex may occur upon divalent cation-dependent complex formation with a protein ligand [31]. Moreover, the

including an inactive cache domain have been linked to ASD (violet bars) and BPD (green bars). $\alpha_{2} \delta-4$ protein mutations are so far only known to cause night blindness (NB) and gliomas (not indicated). ASD (violet), autism spectrum disorders; BPD (green), bipolar disorder; CA (blue), cerebellar atrophy; EE (blue), epileptic encephalopathy; MDD (red), major depressive disorder; NB (gray), night blindness; ND (nude), nicotine dependence; P (bordeaux), pain; SCZ (magenta), schizophrenia

MIDAS site is involved in protein-protein interactions that are required to promote the anterograde transport of calcium channels $[14,48]$. A perfectly conserved MIDAS motif is not required for metal ion binding [112]; however, it is not yet known whether differences in the MIDAS motif between $\alpha_{2} \delta$ subunits 
might account for functional heterogeneity. A role of $\alpha_{2} \delta$ in extracellular protein interactions is further supported by the presence of cache domains, putative protein interaction sites with homology to the extracellular domains of bacterial chemosensing proteins $[2,31]$.

\section{$a_{2} \delta$ proteins as subunits of voltage-gated calcium channels}

VGCCs are critical components of all types of excitable cells. They translate membrane depolarization into cellular functions like skeletal and cardiac muscle contraction, nerve cell signaling, hormone secretion, as well as the regulation of gene transcription. In the central nervous system, calcium channels are particularly involved in presynaptic neurotransmitter release and postsynaptic signaling. VGCCs are classified into three low-voltage-gated $\left(\mathrm{Ca}_{\mathrm{V}} 3.1-3.3\right)$ and seven high-voltage-gated $\left(\mathrm{Ca}_{\mathrm{V}} 1.1-1.4, \mathrm{Ca}_{\mathrm{V}} 2.1-2.3\right)$ channels. High-VGCCs constitute protein complexes classically consisting of a main pore-forming $\alpha_{1}$ subunit and auxiliary intracellular $\beta\left(\beta_{1-4}\right)$ and extracellular membrane-attached $\alpha_{2} \delta\left(\alpha_{2} \delta-1\right.$ to $\left.\alpha_{2} \delta-4\right)$ subunits. While the biophysical channel properties are defined by $\alpha_{1}$ subunits, $\beta$ subunits regulate membrane expression and other modulatory functions (reviewed in [11]). A wealth of heterologous co-expression studies has illustrated the roles of $\alpha_{2} \delta$ proteins as calcium channel subunits. Depending on the co-expressed $\alpha_{1}$ subunit, $\alpha_{2} \delta$ subunits enhance current densities, modulate activation and inactivation kinetics, and can account for a hyperpolarizing shift in the voltage dependence of activation and inactivation (reviewed in $[31,56,75]$ ). The main proposed mechanism underlying the $\alpha_{2} \delta$-induced increase in maximum current is an enhanced plasma membrane expression of channel complexes coupled with a decrease in their turnover [31]. Although it is still elusive how $\alpha_{2} \delta$ subunits implement their effects, the MIDAS motif seems to be essential, since a MIDAS mutant of $\alpha_{2} \delta-2$ causes intracellular retention of $\alpha_{1}$ subunits [14]. Due to their extracellular localization, $\alpha_{2} \delta$ subunits may also link extracellular signaling entities directly to the calcium channel complex.

\section{Calcium channel-independent roles of $a_{2} \delta$ proteins}

An increasing number of recent studies suggests that individual $\alpha_{2} \delta$ isoforms exert specific neuronal functions beyond their classical role as calcium channel subunits. Hence, the affinity and strength of the interaction between $\alpha_{1}$ and $\alpha_{2} \delta$ are under debate (see discussion in [75]). For example, a comprehensive quantitative study of the neuronal $\mathrm{Ca}_{\mathrm{V}} 2$ channel proteome revealed molar ratios of $0.1-1 \%$ of $\alpha_{2} \delta$ compared to $\alpha_{1}$ and $\beta$ subunits [71], suggesting a relatively weak and possibly dynamic association. These findings are further corroborated by single-molecule tracking displaying that $\alpha_{1}$ and $\alpha_{2} \delta$ are only transiently confined together at the cell surface of hippocampal neurons $[10,96,119]$, and that $\alpha_{2} \delta-2$ accumulation in lipid rafts may be partly independent from its interaction with presynaptic calcium channels [24]. Recent studies particularly implicate $\alpha_{2} \delta$ proteins as important regulators of synaptic functions and synapse formation, and these functions may be partly or entirely independent of the calcium channel complex (e.g. [18, 35, 40, 59, 97]).

\section{$a_{2} \delta$ proteins and neurological disorders}

Dysfunctions of voltage-gated calcium channels have been linked to a variety of neurological disorders including Parkinson's disease, epilepsy, migraine, ataxia, neuropathic pain, and psychiatric disorders $[3,8,17,43,80,89,105$, $107,132]$. Hence, it is not surprising that likewise $\alpha_{2} \delta$ proteins have been associated with many of these diseases. The link to neurological disorders is further strengthened by the existence of a variety of knockout and mutant mouse models, which partly represent pathological features of identified human diseases (reviewed in [39]). In the last years, various genome-wide association studies (GWAS) as well as exome sequencing studies have contributed to identifying risk genes for neurological disorders and disease mutations. A further effort in detecting potential disease related genes has been made by single nucleotide variant (SNV) analysis and single nucleotide polymorphism (SNP) genotyping. Along these lines, copy number variation (CNV) analysis contributed largely to the understanding of disease predisposition. SNPs are point mutations of both coding and noncoding DNA regions that occur at a frequency of $0.5-1 \%$ in the population. SNV refers to a variation of a single nucleotide mostly arising in somatic cells. Both SNPs and SNVs can affect gene transcription or may generate splice sites. CNV is a form of variation, which affects the number of copies of a gene, resulting in increased or reduced protein expression. In the following sections, we give an overview of known and proposed $\alpha_{2} \delta$ disease associations. To this end, we distinguish between disease mutations in the proteins, which have been at least partially verified or discovered in specific patients and identified genetic disease associations for the human genes CACNA2D1-4, which partially lack experimental confirmation.

\section{Disease mutations in $\alpha_{2} \delta$ proteins}

Here, we briefly summarize human $\alpha_{2} \delta$ protein mutations, which were identified in PubMed, ClinVar, and SFARI Gene databases and which can be traced back to at least one patient. However, until today, the functional consequences of these mutations were either not or only partially characterized. 
$a_{2} \delta-1$

Missense or protein-disrupting mutations in $\alpha_{2} \delta-1$ have mainly been found in epileptic disorders (Fig. 1, h $\alpha_{2} \delta$ 1). Two large genomic deletions affecting the genetic region of $\alpha_{2} \delta-1$, a de novo mutation (8.2 Mb deletion) and an inherited mutation (3.9 $\mathrm{Mb}$ deletion), were identified in patients with epileptic encephalopathy [68]. The same study identified additional inherited disease mutations (p.Ser709Asn and p.Asp1045Ala) occurring in two families: family 1 with an unaffected mother and dizygotic twin having the same mutation and family 2 with an unaffected father and affected monozygotic twin having the same mutation. Another de novo mutation (p.Val875fs) was discovered in a West syndrome patient [44]. A whole exome sequencing (WES) study revealed a de novo mutation p.Arg351Thr in a family of the Simons Simplex Collection (SSC) of patients with autism spectrum disorders (ASDs) [51].

\section{$a_{2} \delta-2$}

Disease mutations in $\alpha_{2} \delta-2$ have been identified in epileptic encephalopathy and cerebellar ataxia patients (Fig. 1, h $\alpha_{2} \delta-2$ ). Edvardson et al. [34] described the p.Leu1040Pro mutation located in exon 36, close to the missense mutation p.Asp991Asn in exon 34 [115]. Another missense mutation (p.Pro261Leu) was identified in exon 7 [12]. Punetha et al. [84] found two families with epileptic encephalopathy: one displayed a missense variant mutation in exon 20 (p.Arg593Pro) while the other family exhibited a nonsense mutation in exon 5, predicting a severely truncated protein (p.Tyr162Ter). Furthermore, a CACNA2D2 variant (A900T) was found in schizophrenia (SCZ) patients within a Spanish population [92]. Finally, a frameshift mutation in exon 13 (p.Asn432fs) is likely causal in a family with epileptic encephalopathy [81].

\section{$a_{2} \delta-3$}

Potential disease-causing mutations in $\alpha_{2} \delta-3$ were identified in patients with ASDs (Fig. 2, h $\alpha_{2} \delta-3$ ). Exome sequencing identified several synaptic, transcriptional, and chromatin genes disrupted in ASD including the $\alpha_{2} \delta-3$ mutations p.Arg578Gln, p.Arg665Cys, p.Ala698Thr, p.Arg731Gly, p.Asp756Asn, p.Arg205Gly, and p.Glu508Ter [28]. $\alpha_{2} \delta-3$ de novo gene mutations were also found in a Chinese ASD cohort (p.Ala773Val and p.Ala275Thr) [121] and in probands from the autism clinical and genetic resources in China (p.Ala917Thr and p.Ala698Val) [42]. $a_{2} \delta-4$

$\alpha_{2} \delta-4$ mutations are strongly involved in retinal disease and gliomas, which go beyond the scope of the current review. However, we would like to highlight two prominent mutations (Fig. 2, h $\alpha_{2} \delta-4$ ), which affect $\alpha_{2} \delta-4$ expression or structure and may, in theory, also affect the previously suggested expression of $\alpha_{2} \delta-4$ in the brain $[95,117]$. A mutation found in night blindness (p.Tyr802Ter) results in a premature stop at amino acid 802. However, it is expected that the mutated messenger RNA (mRNA) is recognized by the nonsensemediated decay machinery [127]. Another mutation that deserves mentioning is p.Arg707His found to be involved in cone-rod dystrophy [4]. In addition, large genomic deletions affect $\alpha_{2} \delta-4$ protein expression and thereby cause retinal degeneration and night blindness. So far, no brain-related phenotypes were reported, although the gene has been identified as a risk gene for psychiatric disorders. One deletion of $35,740 \mathrm{bp}$ comprising amino acids $574-850$ was found in patients with bipolar disorder (BPD) [116].

\section{Genetic disease associations}

In this chapter, we briefly summarize human CACNA2D disease associations, which were identified in PubMed, ClinVar, and dbSNP databases. Mutations and SNPs that were not validated in separate publications were not included.

\section{CACNA2D1}

Over the past years, various genetic studies implied CACNA2D 1 , the gene encoding the $\alpha_{2} \delta-1$ isoform, in various forms of epilepsy and psychiatric disorders including major depressive disorders (MDDs), BPD, and SCZ (Fig. 1, CADNA2D1). In GWAS, CACNA2D1 was identified as a potential drug target in MDD [49] and SNP rs17156280 was associated with an interaction between depressive states and stressful events [50]. Furthermore, two SNPs (rs258668 and rs258677) were linked to depressive traits such as subjective well-being and neuroticism [76]. GWAS analysis of data from the Bipolar Disorder Genome Study Consortium [125] identified SNP rs2367911 as a risk for BPD with comorbid binge eating. In a haplotype analysis on Han Chinese population, two SNPs (rs37076|rs37093 G-C and rs10265730|rs258665 G-A) were associated with SCZ [134]. Within a Swedish population, a disruptive (frameshift) variant in CACNA2D1 has been identified in an exome sequence of schizophrenia patients [85]. A large deletion of CACNA2D1 was found in one SCZ patient in a Japanese population [66]. By comparing epileptic patients with control subjects, 23 SNPs were identified, of which 6 occurred exclusively in affected individuals [55]. From these 6 SNPs, one was located in the coding sequence (exon 11), one in the 3' UTR, while the other 4 SNPs 
were located in introns including SNP (rs2302384), which was already known from the dbSNP database. Importantly, chromosomal deletions affecting CACNA2D1 were identified in three patients with epilepsy and intellectual disability [118].

\section{CACNA2D2}

Three de novo variations in CACNA2D2 (Fig. 1, CACNA2D2) were found in patients with SCZ [85]. Two out of three CACNA2D2 variations introduced premature stop codons while the third variant was predicted to disrupt a splice donor site (Purcell A/C). Another CACNA2D2 SNP (rs11917269) has been associated with BPD [103].

\section{CACNA2D3}

Initially, the gene encoding for $\alpha_{2} \delta-3$ was characterized as a target for pain treatment, since the SNP rs6777055 was associated with reduced thermal pain response [72]. Nevertheless, more recently, CACNA2D3 has been linked to neurodevelopmental disorders such as SCZ, BPD, MDD, nicotine dependence (ND), and especially to ASD [52] (Fig. 2, CACNA2D3). For example, the genetic region of CACNA2D3 (3p14) was associated with SCZ and an endophenotype related to the function of the temporal lobe, the anti-saccade reflex [63]. In another study, pathway analysis of SCZ risk SNPs suggested an association of CACNA2D3 with the response to lurasidone, an antipsychotic drug used to treat SCZ [62]. Furthermore, regional enrichment analysis associated the genomic region 3p21.1_1, which also contains CACNA2D3, with SCZ and BPD [63], a link which also is supported by other studies [63, 67, 70,101, 134]. While the abovementioned SNPs are all located in exons, one intronic SNP (rs75407252) has been linked to MDD [33]. Associations with ASD were identified in whole genome sequencing studies as inherited variations resulting in splicing disruption [131] or as CNVs [41]. Moreover, SNP rs3773540 was among the top 15 SNPs contributing to ASD diagnosis [100] and a splice site mutation at the beginning of exon 24 was identified in an ASD patient [52]. In their exome sequencing study, De Rubeis et al. [28] further identified several inherited variations in CACNA2D3 with so far unknown effect. Finally, 30 CACNA2D3 SNPs were identified in a study on epilepsy, of which 6 occurred in epileptic patients [55].

\section{CACNA2D4}

$\alpha_{2} \delta-4$ is almost exclusively expressed in the retina, pituitary gland, and adrenal gland [29, 88]. However, very low levels are also detected in the hippocampus and are upregulated during development and status epilepticus [95, 117]. A possible role in the brain, which is further outlined below, is suggested by several SNPs linked to numerous neurological disorders.
For instance, a SNP located between the CACNA2D4 and CACNA1C genes (rs1024582) was significantly associated with cross-disorders that included attention deficit hyperactivity disorder (ADHD), BPD, ASD, SCZ, and MDD [22]. A de novo frameshift mutation likely disrupting CACNA2D4 was found in patients with SCZ [85] (Fig. 2, CACNA2D4). Another endophenotype of SCZ is default mode network, which was found to associate with the SNP rs4765847 [67]. SNPs rs2041140 and rs2041141 were linked to BPD [83], and partial deletions of $35.7 \mathrm{~kb}$, eliminating exons $17-26$, were found in two unrelated patients with late-onset BPD, one deletion was found in control individuals [116]. A WES study, comparing brain samples from MDD patients that died from suicide with MDD patients dying from unrelated causes, found a splice donor variant (C/A) [111]. Furthermore, a rare homozygous deletion affecting CACNA1C and CACNA2D4 (12p13.33) was found in a male ASD patient [102]. Thirtynine SNPs were associated with epilepsy, of which 13 were exclusively found in the patients and not in controls [55] (Fig. 2, CACNA2D4).

\section{Potential disease mechanisms}

The overall picture of identified disease mutations suggests the involvement of $\alpha_{2} \delta$ proteins in epilepsy (particularly $\alpha_{2} \delta-2$ but also $\alpha_{2} \delta-1$ ) and ASD (mainly $\alpha_{2} \delta-3$ but also $\alpha_{2} \delta$ $1)$. The majority of identified mutations represent missense mutations resulting in single amino acid substitutions and, to a lesser extent, protein truncations resulting in the complete or partial loss of $\alpha_{2} \delta$ proteins (e.g. p.Tyr162Ter in $\alpha_{2} \delta-2$ or p.Glu508Ter in $\alpha_{2} \delta-3$ ). When considering genetic disease associations, the picture becomes more diverse and links $\alpha_{2} \delta$ genes additionally to MDD $\left(\alpha_{2} \delta-1, \alpha_{2} \delta-2\right.$, and $\left.\alpha_{2} \delta-3\right)$, SCZ $\left(\alpha_{2} \delta-1, \alpha_{2} \delta-2, \alpha_{2} \delta-3\right.$, and $\left.\alpha_{2} \delta-4\right)$, BPD $\left(\alpha_{2} \delta-1, \alpha_{2} \delta-2\right.$, and $\left.\alpha_{2} \delta-4\right)$, and ND $\left(\alpha_{2} \delta-3\right)$ [129]. While some of the described SNPs are in exons and most likely result in missense mutations, many are found in intronic DNA stretches or are affecting splice sites. As $\alpha_{2} \delta$ proteins, on the one hand, are important modulators of calcium channels and, on the other hand, are independent regulators of synaptic functions, disease mutations can affect these functions either independently or concomitantly. In order to understand which cellular functions may be compromised by $\alpha_{2} \delta$ mutations, we will here recapitulate evidence for the involvement of $\alpha_{2} \delta$ proteins in calcium channel-dependent and calcium channel-independent functions.

\section{Calcium channel-dependent mechanisms}

In heterologous co-expression studies, all $\alpha_{2} \delta$ proteins show similar effects on channel surface expression (reviewed in [25, 39, 57]) (Fig. 3, point 1). In contrast, evidence in differentiated 


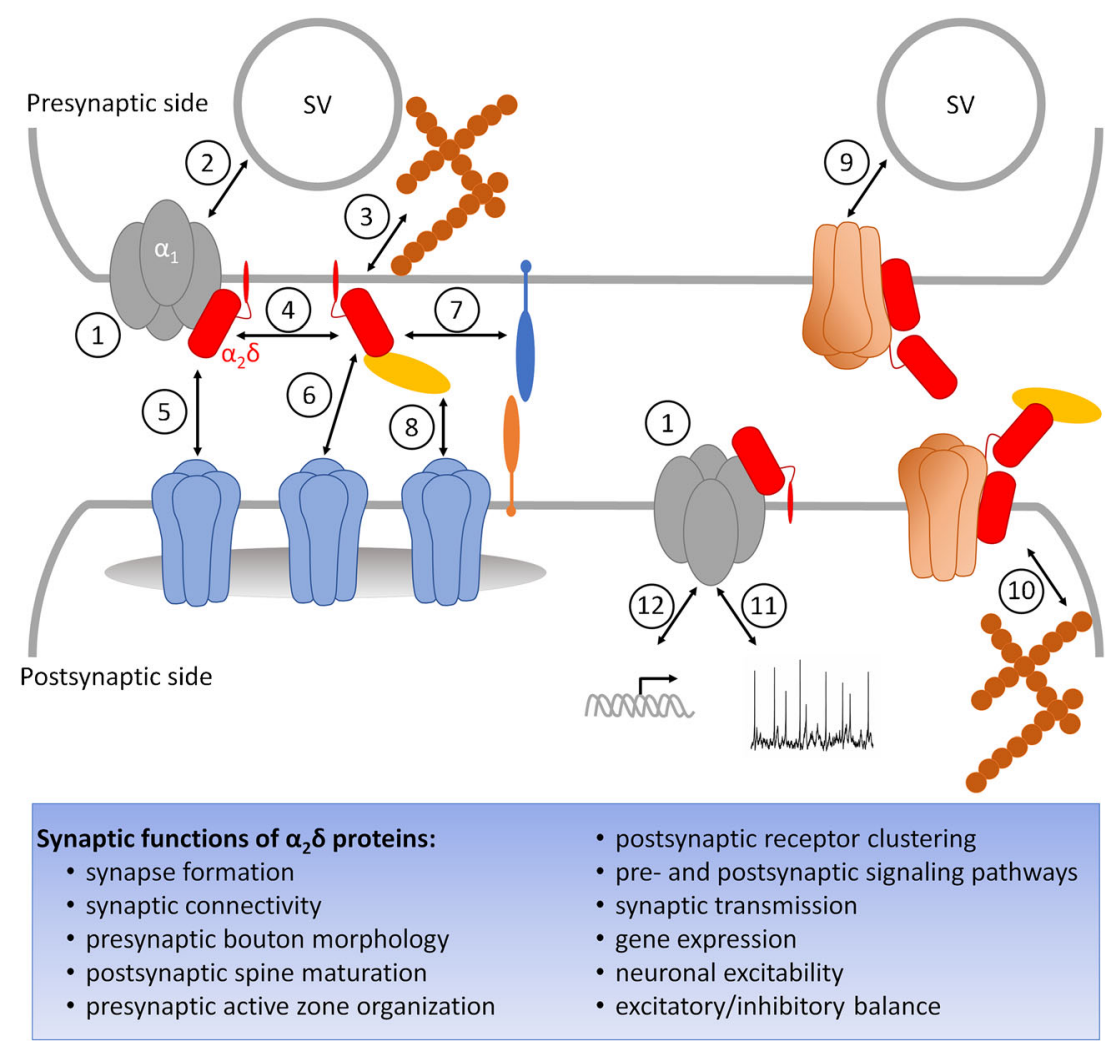

Fig. 3 Model summarizing proposed synaptic functions of $\alpha_{2} \delta$ proteins. $\alpha_{2} \delta$ proteins as calcium channel subunits enhance plasma membrane expression and modulate current properties of both presynaptic and postsynaptic $\alpha_{1}$ subunits (1). At the presynaptic terminal, $\alpha_{2} \delta$ proteins mediate the accumulation of synaptic vesicles $(\mathrm{SV}, 2)$. They regulate active zone architecture (AZ) and bouton morphogenesis (3) either directly by interacting with proteins of the $\mathrm{AZ}$ and cytoskeleton (3) or indirectly via the VGCC complex (4). By aligning the presynaptic AZ with the postsynaptic membrane and postsynaptic AMPAR and $\mathrm{GABA}_{\mathrm{A}} \mathrm{R}$ (receptors in blue; 5 and 6 , respectively), they act as transsynaptic organizers either partly (5) or entirely (6) independent of the VGCC complex. This may be mediated by a direct interaction with

native cellular systems suggests at least a partial isoform specificity. In rat superior cervical ganglion neurons, for example, recombinant expression of $\alpha_{2} \delta-1$ and $\alpha_{2} \delta-2$ differently affected $\mathrm{Ca}_{\mathrm{V}} 2.2$ expression when compared with $\alpha_{2} \delta-3$ [98]. In mice, genetic ablation of $\alpha_{2} \delta-1$ abolishes $\mathrm{Ca}_{\mathrm{v}} 2.2$ cell surface expression in dorsal root ganglion (DRG) neurons and dramatically reduces dorsal horn expression [73]. Deletion of $\alpha_{2} \delta-3$ differentially affects calcium currents; it reduces P/Qand R-type currents, while $\mathrm{N}$ - and L-type remain unaltered [104]. Loss of $\alpha_{2} \delta-3$ blocks homeostatic modulation of neurotransmitter release due to a failure to potentiate presynaptic calcium influx [122].

Kinetic and voltage-dependent properties of the channels are also modulated by $\alpha_{2} \delta$ proteins: depending on the channel type and the native channel environment, activation and inactivation kinetics can be slowed or accelerated $[74,75,114,120]$. The voltage dependence of steadystate inactivation is generally hyperpolarized by $\alpha_{2} \delta$ [36], postsynaptic receptors (6), by interacting with prototypical cell adhesion molecules such as presynaptic neurexins and postsynaptic neuroligins (7), or by interacting with proteins of the extracellular matrix or secreted proteins (e.g. BDNF, TSP; yellow ellipses) (8). A transmembrane form of $\alpha_{2} \delta-1$ bound to TSP is suggested to initiate the recruitment and stabilization of NMDAR (receptors in auburn) on the presynaptic (9) and postsynaptic (10) surface, a mechanism which contributes to enhanced synaptic transmission (9) and regulates intracellular signaling pathways as well as dendritic spine maturation via a small Rho GTPase (10). By regulating calcium currents of VGCC, $\alpha_{2} \delta$ proteins are further predicted to modulate neuronal excitability (11) and gene expression (12)

while a shift to more positive potential is observed in individual cases [87]. In this context, it is noteworthy that the presence of $\alpha_{2} \delta$ - 1 facilitates channel activation by increasing the voltage sensitivity of the channel's voltage-sensing domains [93]. Another important structural property of $\alpha_{2} \delta$ which affects calcium currents includes the VWA domain, as a MIDAS mutant of $\alpha_{2} \delta-2$ subunit failed to enhance $\mathrm{Ca}_{\mathrm{V}} 1.2, \mathrm{Ca}_{\mathrm{V}} 2.1$, and $\mathrm{Ca}_{\mathrm{V}} 2.2$ currents [14].

In neurons of the brain and the sensory nervous system, calcium channel function can also be influenced by altered or aberrant interaction of $\alpha_{2} \delta$ proteins with other identified interaction partners. For example, thrombospondin (TSP)- 4 can increase calcium currents after low-voltage depolarization and contributes to aberrant excitatory synaptogenesis associated with neuropathic pain development; both of these effects can be blocked by gabapentin [77, 130]. The synaptic celladhesion molecules $\alpha$-neurexins together with $\alpha_{2} \delta$-1 regulate presynaptic calcium influx through $\mathrm{Ca}_{\mathrm{V}} 2.1$ channels [10] 
(Fig. 3, points 1, 4, and 7). The inhibitory effect of prion protein [99] may be modulated by competing with $\alpha_{2} \delta$ for GPI-anchoring pathways [1]. Moreover, low-density lipoprotein receptor-related protein 1 (LRP1) reduces $\alpha_{2} \delta-1$ trafficking and hence influences trafficking of $\mathrm{Ca}_{\mathrm{V}} 2.2$ to the cell surface [53]. Another protein suggested to influence VGCC function by interacting with $\alpha_{2} \delta-1$ is the $\alpha$ subunit (Slo1) of the large conductance calcium-activated potassium (BK) channel [133]. Following spinal nerve injury, Slo1 regulates excitability by preventing the association of $\alpha_{2} \delta-1$ and $\alpha_{1}$ subunits, resulting in reduced functional membrane expression of $\mathrm{Ca}_{\mathrm{V}} 2.2$ and analgesia. Similar mechanisms to counteract neuronal hyper-excitability might also be relevant in pathologic conditions, for example in epilepsy.

It is worth mentioning that an $\alpha_{2} \delta$-like protein, CACHD1, has recently been characterized [20]. CACHD1 causes a functional increase of low voltage-activated T-type $\left(\mathrm{Ca}_{\mathrm{V}} 3\right)$ currents, which are not modulated by classical $\alpha_{2} \delta$ proteins. However, despite having a disrupted MIDAS motif, rat Cachd 1 also can increase $\mathrm{Ca}_{\mathrm{V}} 2.2$ currents and surface expression upon heterologous co-expression [23].

Taken together, it is well established that $\alpha_{2} \delta$ proteins have significant effects on the biophysical properties of calcium channels, particularly on calcium current density, activation and inactivation kinetics, and voltage dependence of activation and inactivation. Thus, potential mutations affecting $\alpha_{2} \delta$ expression levels, glycosylation, or attachment of the GPI anchor may generally affect calcium channel surface expression and hence calcium currents. The p.Leu1040Pro mutation associated with epilepsy [34] resulted in reduced current densities and slowed inactivation when co-expressed with neuronal calcium channels. Similarly, a point mutation in the VWA domain, identified in a patient with autism (p.Arg351Thr) [51], prevents stable plasma membrane expression of $\alpha_{2} \delta-1$ in a heterologous expression system [90]. Both mutations suggest that these effects can be mediated via altered expression of presynaptic and postsynaptic calcium channels or defective calcium currents which may, ultimately, result in an aberrant excitatory-inhibitory balance and underlie the pathophysiology of the associated diseases (Fig. 3). Interestingly, structurehomology modeling revealed two critical interactions of Arg351 (data not shown); hence, a significant effect of the exchange to $\mathrm{Thr}$ on the protein structure is possible. However, it is important to note that for the majority of identified human $\alpha_{2} \delta$ mutations, the structure-function consequences have not yet been studied.

\section{Channel-independent synaptic functions of potential relevance for neurological disorders}

In this chapter, we summarize novel synaptic roles of $\alpha_{2} \delta$ proteins, which, alone or in combination with channeldependent functions, may be casually involved in neurological disorders: synapse formation, synaptic connectivity and postsynaptic receptor abundance, presynaptic architecture, and synaptic transmission (Fig. 3). The link between synaptic $\alpha_{2} \delta$ proteins and brain disorders is particularly relevant, as a common feature of neurological disorders is their linkage to synaptic dysfunctions, referred to as synaptopathies (reviewed in [113]). This particularly accounts for neurodevelopmental disorders such as ASD, intellectual disability (ID), Fragile X syndrome (FXS), Down syndrome, ADHD, epilepsy, neuropsychiatric disorders (e.g. BPD, $\mathrm{SCZ}$ ), MDD, and neurodegenerative diseases such as Alzheimer's, Huntington's, and Parkinson's diseases. Correct assembly of glutamatergic and GABAergic synapses comprises a series of intricate steps, including the contact of presynaptic axons with specific cellular postsynaptic compartments of target cells, as well as the recruitment of presynaptic and postsynaptic proteins to form a functional synapse (reviewed in $[21,38,61,110]$ ). Hence, aberrant expression of individual synaptic proteins as well as mutations affecting their function might cause perturbations in synapse physiology and morphology. This, in turn, could lead to synaptic dysfunction, an imbalance of synaptic excitation and inhibition (E/I imbalance), abnormalities in wiring of neuronal circuits, and finally, the development of a neurological disease.

\section{$a_{2} \delta-1$ mediates excitatory synaptogenesis}

The interaction of postsynaptic $\alpha_{2} \delta-1$ and its astrocytesecreted ligand TSP mediates excitatory synapse formation in retinal ganglion cells, and the study suggests that $\alpha_{2} \delta-1 /$ TSP-induced synaptogenesis does require neither presence nor function of $\alpha_{1}$ subunits [35]. A follow-up study [90] demonstrated that loss of $\alpha_{2} \delta-1$ in a conditional knockout mouse strain [78] impairs excitatory synaptogenesis and spine morphology in the cortex (Fig. 3, point 10). Interestingly, a point mutation in the VWA domain of $\alpha_{2} \delta-1$, which has been linked to autism in humans [51], prevented both membrane trafficking of $\alpha_{2} \delta-1$ (see above) and the rescue of the synaptogenic defects. These findings suggest that the previously identified $\alpha_{2} \delta-1$ disease mutation might underlie impaired excitatory synapse formation and synaptic transmission. The study by Risher et al. [90] also proposes that TSP binding to a transmembrane form of $\alpha_{2} \delta-1$ initiates the recruitment and stabilization of NMDA receptors (NMDARs) on the postsynaptic surface, a mechanism which may consequently contribute to dendritic spine maturation (Fig. 3, point 10). The idea that $\alpha_{2} \delta-1$ may be also associated with presynaptic function is further suggested by studies addressing its involvement in neuropathic pain [18], hyperalgesia [30], and cultured hippocampal neurons [7]. Increased $\alpha_{2} \delta-1$ expression levels via lentiviral injection [18] or induced by opioid application [30] potentiated presynaptic NMDAR trafficking in spinal cord synapses (Fig. 3, point 9). Excitatory synaptic transmission 
was enhanced, ultimately provoking pain hypersensitivity, which could be normalized with either gabapentin or an $\alpha_{2} \delta-1$ interfering peptide. The causative interaction of $\alpha_{2} \delta-1$ with a set of distinct NMDAR subtypes (GluN1, GluN2A, and GluN2B) is presumably specific, as neither $\alpha_{2} \delta-2$ nor $\alpha_{2} \delta-3$ co-immuno-precipitated with NMDARs in the spinal cord and HEK cells [18]. To unravel the NMDAR interaction site within the $\alpha_{2} \delta-1$ sequence, a chimeric approach was used, substituting the C-terminus, $\alpha_{2}$, or $\delta$ peptide of $\alpha_{2} \delta$-1 with that of $\alpha_{2} \delta-2$ or $\alpha_{2} \delta-3$. Surprisingly, the interaction domain was identified to be located after the C-terminal GPI anchor cleavage site. As earlier studies revealed that $\alpha_{2} \delta$ subunits have hardly any or no cytoplasmic domain [26], these data might corroborate the abovementioned findings that NMDARs bind to a transmembrane form of $\alpha_{2} \delta-1$ (for further detail and discussion, see [32, 46]) (Fig. 3, points 9 and 10). Both the hypothalamus $[64,65]$ and striatum [136] express presynaptic and postsynaptic $\alpha_{2} \delta-1 /$ NMDAR complexes, augmenting NMDAR-mediated synaptic glutamate release in disease (hypertension) [64, 65] and under physiological conditions (corticostriatal long-term potentiation in learning and memory) [136]. However, since a proteomic study of native rat brain [79] could not identify $\alpha_{2} \delta$ subunits in NMDAR-rich postsynaptic densities, it is conceivable that NMDAR $/ \alpha_{2} \delta-1$ association might represent a rather dynamic form of neuronal signaling primarily relevant in neuropathological conditions.

It has been recently suggested that brain-derived neurotrophic factor (BDNF) might be an upstream regulator of neuronal $\alpha_{2} \delta-1$ expression levels $[9,19,86]$. Lack of BDNF in mice causes reduced $\alpha_{2} \delta-1$ cell surface expression in the ventromedial hypothalamus, likely affecting excitatory synapse formation without obviously altering calcium currents [19]. Moreover, BDNF mutant mice recovering from stroke display increased abundance of $\alpha_{2} \delta-1$ and TSP2 together with a concomitant enhancement of glutamatergic synapses within the cortico-striatal pathway [86]. Importantly, as the study further identified a reduction of GABAergic innervation in distinct cortical layers, these data might suggest that synaptic $\alpha_{2} \delta-1$ expression levels regulate the balance of excitation to inhibition.

\section{$a_{2} \delta-2$ splice variants regulate synaptic connectivity and postsynaptic receptor abundance}

Recent evidence suggests that presynaptic $\alpha_{2} \delta-2$ potently regulates synaptic connectivity and postsynaptic receptor abundance at specific central synapses. For instance, we previously found that solely $\alpha_{2} \delta$ splice variants lacking exon 23 regulate both the wiring of presynaptic axons to GABAergic postsynaptic sites, as well as postsynaptic $\mathrm{GABA}_{\mathrm{A}}$ receptor $\left(\mathrm{GABA}_{\mathrm{A}} \mathrm{R}\right)$ abundance [40] (Fig. 3, points 5 and 6). As heterologous co-expression of distinct $\alpha_{2} \delta-2$ splice variants with various $\alpha_{1}$ subunits caused similar effects on calcium current densities and activation/inactivation kinetics [45], these data suggest that the trans-synaptic function of $\alpha_{2} \delta$-2 variants lacking exon 23 is independent of their role as a calcium channel subunit. Interestingly, $\alpha_{2} \delta-2$ is also necessary for the proper spatial alignment of presynaptic L-type calcium channels and postsynaptic AMPA receptors in hair cell synapses of the inner ear [37], as well as for the structure and function of cerebellar climbing fiber synapses [5]. While the distinct signaling pathways remain to be determined, it is thus tempting to speculate that glutamatergic and GABAergic synapses may express a specific set of presynaptic $\alpha_{2} \delta$ isoforms and even splice variants in order to regulate synaptic connectivity and postsynaptic receptor abundance during development (Fig. 3, points 5 and 6). Along these lines, previous studies have proposed developmental functions of an $\alpha_{2} \delta-2$ variant lacking exon 23 in establishing neuronal circuits [106, 108, 109]. As murine axonal projections of DRG neurons mature during embryonic development, they undergo a switch from a growth-competent (electrically dormant) to a transmitting (electrically active) phase, which also correlates with increased $\alpha_{2} \delta-2$ expression levels [108]. Whether $\alpha_{2} \delta-2$ regulates axon growth of sensory neurons by altering $\alpha_{1}$ subunitmediated neurotransmission needs to be clarified. However, recent findings in mouse cortical neurons show that $\alpha_{2} \delta-2$, which is specifically expressed at the soma, axons, and growth cones of corticospinal layer $\mathrm{V}$ neurons, displays distinct postnatal expression patterns [106]. Therefore, increased $\alpha_{2} \delta-2$ expression levels during development accompany increased spontaneous firing at a time point when cortico-spinal axon growth is nearly completed, and synaptogenesis begins.

Altogether, several lines of evidence suggest the existence of distinct spatiotemporal expression patterns of $\alpha_{2} \delta-2$ regulating synapse connectivity and specificity, which may even depend on exon usage [40]. Since the amount of $\alpha_{2} \delta$-2 protein is also increased in pathological conditions such as spinal cord injury [106, 108], abnormal expression levels likely contribute to maladaptive synaptogenesis or plasticity, ultimately leading to aberrant neuronal networks.

\section{$a_{2} \delta-3$ regulates size, morphology, and architecture of presynaptic boutons}

Most of today's knowledge on the role of $\alpha_{2} \delta-3$ in synaptic transmission and synapse formation is based on studies conducted in invertebrate model systems. Caylor et al. [16] showed, for instance, that in Caenorhabditis elegans, homologs of $\mathrm{Ca}_{\mathrm{V}} 2$ (UNC-2), $\alpha_{2} \delta$ (UNC-36), and CaMKII (UNC43) regulate the size and morphology of GABAergic motoneuron terminals in neuromuscular junctions (NMJs) (Fig. 3, point 3). In Drosophila melanogaster null mutants of the $\alpha_{2} \delta$ 3 homolog straightjacket (stj), motoneuron terminals of NMJs fail to develop presynaptic boutons showing a severely 
disrupted cytoskeleton [59]. Nevertheless, growth cones successfully navigate and halt at their target muscles, indicating that initial contact formation of synapses is normal but followed by an arrest of morphogenesis during larval development. Although the synapse-stabilizing protein ankyrin-2 is absent, functional presynaptic specializations are present and properly opposed to postsynaptic clusters of glutamate receptors. The $\mathrm{Ca}_{\mathrm{V}} 2$ homolog cacophony, however, is missing in active zones, consistent with an inability to evoke synaptic release. Both bouton formation and function could be rescued when expressing an $\alpha_{2} \delta-3$ mutant lacking the $\delta$ peptide, suggesting that the synaptogenic function and calcium channel targeting property require the extracellular $\alpha_{2}$ part of the protein. Importantly, the authors demonstrated that bouton formation does not depend on synaptic calcium channel localization, as the $\alpha_{1}$ mutant cacophony displays normal morphogenesis. A recent study might offer a mechanistic explanation how the extracellular $\alpha_{2}$ peptide of $\alpha_{2} \delta$-3 regulates the development of embryonic Drosophila NMJs. Hoover et al. [47] uncovered that presynaptic $\alpha_{2} \delta-3$ promotes the function of an activitydependent autocrine bone morphogenetic protein (BMP) signaling pathway via modulating membrane retention of glass bottom boat (Gbb). Presynaptic Gbb, in turn, serves as a retrograde cue regulating active zone architecture, synaptic vesicle distribution, neurotransmitter release, and bouton morphogenesis. Similar mechanisms might also exist in vertebrate synapse formation, as altered expression of mammalian $\alpha_{2} \delta-3$ has been shown to affect the size and morphology of presynaptic boutons of auditory nerve fibers [82] (Fig. 3, point 3), and GABAergic synapses of central neurons as well as postsynaptic receptor abundance [40] (Fig. 3, points 5 and 6). In hippocampal neurons, overexpression of $\alpha_{2} \delta-3$, in contrast to $\alpha_{2} \delta-1$, facilitated spontaneous GABA release and increased the density of inhibitory synapses [7]. It is important to note that presynaptic $\alpha_{2} \delta-3$ and $\alpha_{2} \delta-2$ may regulate synaptic differentiation and postsynaptic receptor abundance by two independent mechanisms: while overexpression of $\alpha_{2} \delta-3$ induced smaller synapses, associated with reduced content of both presynaptic and postsynaptic proteins, presynaptic $\alpha_{2} \delta$ 2 modulated postsynaptic $\mathrm{GABA}_{\mathrm{A}} \mathrm{R}$ abundance without affecting presynaptic bouton size [40].

\section{$a_{2} \delta-4$ is required for synaptic transmission and wiring of photoreceptors}

$\alpha_{2} \delta-4$ transcript levels by far exceed those of other $\alpha_{2} \delta$ isoforms in retinal photoreceptor cells [58]. Accordingly, mutations in the human, mouse, and zebrafish genes [54, $94,123,127,128]$ and the associated pathological phenotypes underline a general importance of $\alpha_{2} \delta-4$ in maintaining proper rod and cone synaptogenesis and physiology. Because $\alpha_{2} \delta-4$ regulates both functional membrane expression of $\mathrm{Ca}_{\mathrm{V}} 1.4$ channels and synaptic transmission of rods
[123] and cones [54, 94], converging lines of evidence suggest that abnormal $\mathrm{Ca}_{V} 1.4$ expression may be the main cause for synaptic abnormalities of retinal photoreceptor cells. Nevertheless, these studies also implicate the presence of distinct $\alpha_{2} \delta-4$ signaling pathways in rod and cone photoreceptors. For instance, Wang et al. [123] showed that in $\alpha_{2} \delta-4$ knockout mice, the key synaptogenic molecule for rod synaptogenesis (Elfn1) is not recruited to rod synaptic terminals. This prevents rods from establishing contacts with their postsynaptic targets, the ON rod bipolar cells, which disrupt postsynaptic metabotropic glutamate receptor 6 (mGLUR6) clustering. Even though only little structural effects have been reported for cone photoreceptor synapses in this study, synaptic transmission appears to be severely impaired also in cones. A second report using a different $\alpha_{2} \delta-4$ knockout mouse [54] could further extend these findings in revealing that abnormal wiring of cone synapses is associated with impaired cone transmission through ON and OFF bipolar pathways. Nevertheless, abnormalities of ribbon synapses are more severe and $\mathrm{Ca}_{\mathrm{V}} 1.4$ channels are lost faster in terminals of rods than in cones. Because Elfn 1 is not expressed in cone synapses [15], the findings described in both reports $[54,123]$ indicate that loss of $\mathrm{Ca}_{\mathrm{V}} 1.4$ may be the primary cause for synaptic abnormalities in rods and cones. Alternatively, it is conceivable that $\alpha_{2} \delta-4$ regulates rod and cone synapse structure by two distinct mechanisms (one dependent on Elfn1 and one independent from Elfn1). A recent study conducted in zebrafish underpinned a functional divergence and different developmental expression patterns of two $\alpha_{2} \delta-4$ variants in cone photoreceptors [94]. Interestingly, solely the loss of one variant, Cacna2d4b, specifically leads to the occurrence of mislocalized synapses during larval development. Thus, it is tempting to speculate that spatiotemporal expression patterns of distinct $\alpha_{2} \delta-4$ variants might regulate synapse connectivity and specificity of rod photoreceptors.

Until recently, protein and mRNA expression levels of human and murine $\alpha_{2} \delta-4$ seemed negligible in all previously examined CNS regions $[40,88,95]$. A recent study, however, reported increased levels of $\alpha_{2} \delta-4$ mRNA in human hippocampal biopsies obtained from epileptic patients, an interesting finding in spite of the lack of information on absolute mRNA levels [117]. Considering that standard curve-based qRT-PCR studies from our group identified very low amounts of $\alpha_{2} \delta-4$ mRNA in the mouse brain [40,95], the recent findings suggest the existence of a subpopulation of hippocampal neurons expressing $\alpha_{2} \delta-4$. Interestingly, several studies provide a potential link between CACNA2D4 and psychiatric disorders ([116], see discussion therein and above). Yet, it remains to be addressed whether late-onset bipolar disorder might be a secondary effect caused by visual impairments in these patients, or if $\alpha_{2} \delta-4$ might play a more prominent role in central neurons of the brain. 

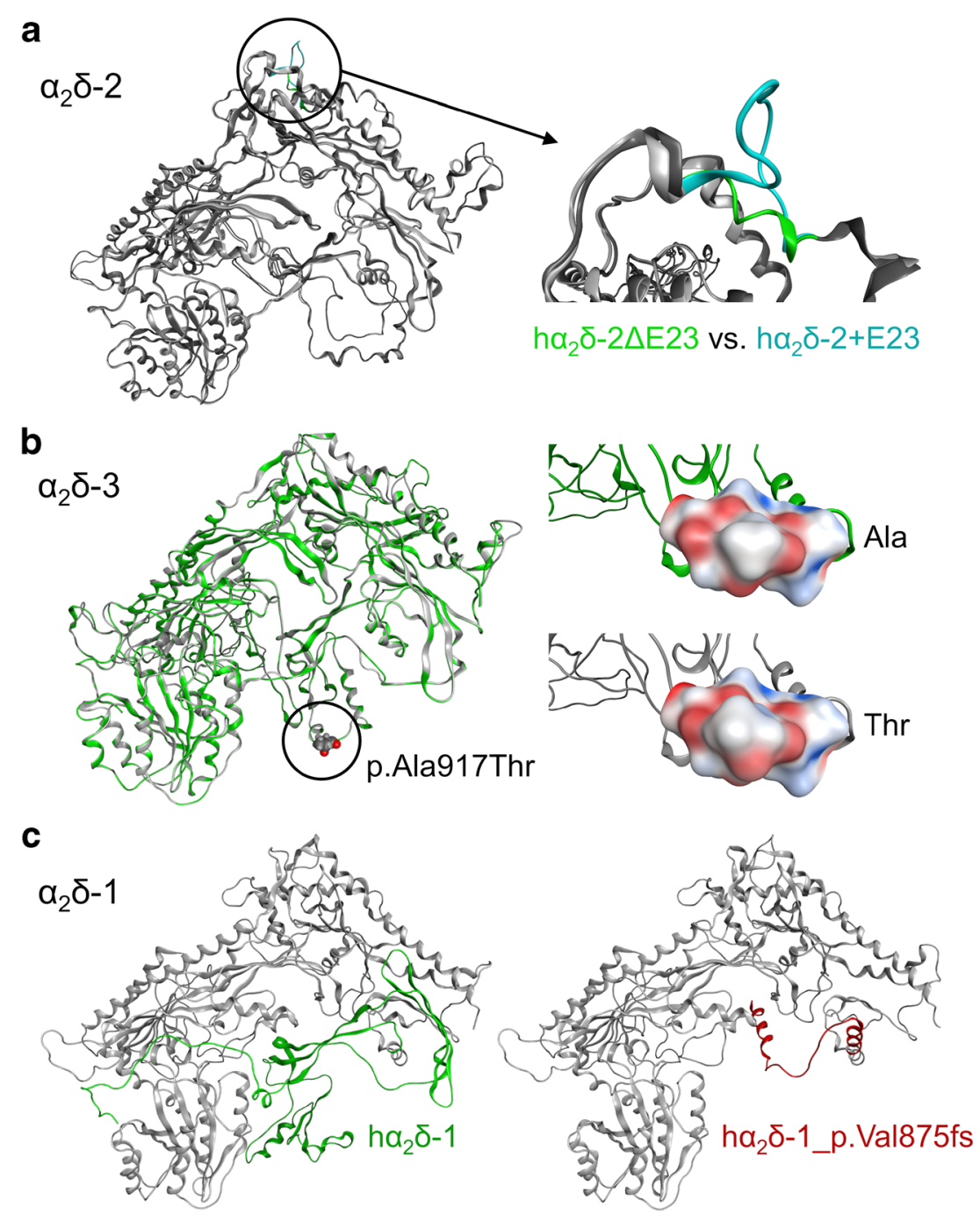

Fig. 4 Putative consequences of $\alpha_{2} \delta$ splicing and selected disease mutations on protein structure. Using homology modeling based on the $2.7 \AA$ resolution structure of $\alpha_{2} \delta-1$ (PDB code: 6JP8) [6, 135], we tested the potential consequences of alternative splicing of exon 23 on the structure prediction of $h \alpha_{2} \delta-2$ (a) [40], the potentially autism-causing mutation p.Ala917Thr in $h \alpha_{2} \delta-3$ (b) [42], and the $h \alpha_{2} \delta-1$ frameshift mutation p.Val875fs associated with epilepsy (c) [44]. a As previously suggested for mouse $\alpha_{2} \delta-2$ [40], the inclusion of exon 23 in $h \alpha_{2} \delta-2$ suggests the formation of an extra loop leading to the disruption of an $\alpha$-helix present. b Mutation p.Ala917Thr is not predicted to alter $h \alpha_{2} \delta-3$ protein structure; however, altered electrostatic potential (EP) on the surface (red, negative EP; blue, positive EP) and hence altered surface hydrophobicity may influence protein interactions. c The $h \alpha_{2} \delta-1$ frameshift mutation p.Val875fs deletes the C-terminal part of $\alpha_{2}$ and the entire $\delta$ peptide (green). Furthermore, the altered reading frame introduces a random 36-amino acid sequence stretch (red). Molecular modeling was performed with the MOE software [69]. EP calculations were performed using Amber 10:EHT charges and the Poisson-Boltzmann approach as implemented in the software. Prior to the calculations, the structure was prepared and protonated with Protonate3D within MOE

\section{How do mutations affect $a_{2} \delta$ protein function?}

Considering the manifold roles involving $\alpha_{2} \delta$ proteins, it is obvious that $\alpha_{2} \delta$ malfunction can affect channel-dependent and channel-independent functions. Particularly, mutations affecting expression levels of $\alpha_{2} \delta$ proteins (e.g. intronic SNPs, protein truncations, $\mathrm{CNV}$ ) may simultaneously affect both functions. Hence, the extent of the disease involvement will mainly depend on the regional and temporal expression of individual $\alpha_{2} \delta$ subunits. For example, this is the case in epileptic encephalopathies and cerebellar ataxias associated with $\alpha_{2} \delta-2$ (predominant expression of $\alpha_{2} \delta-2$ in the cerebellum) or retinal dysfunctions associated with $\alpha_{2} \delta-4$ (predominant expression of $\alpha_{2} \delta-4$ in the retina). Similarly, mutations affecting splicing may primarily affect regions endogenously expressing specific splice isoforms. Although until today regional and temporal expression patterns of $\alpha_{2} \delta$ splice variants are still incompletely understood, splices are indeed relevant for the functional diversity $[40,60]$. However, in contrast to mutations affecting $\alpha_{2} \delta$ protein expression levels, splicing 
Fig. 5 Model summarizing channel-dependent and channelindependent roles of $\alpha_{2} \delta$ proteins. Mutations of $\alpha_{2} \delta$ genes can affect expression levels, protein structure, and splicing. These alterations have consequences on calcium channel-dependent functions (membrane expression, current modulation, channel subtype-specific functions), and channel-independent functions (extracellular and/or transsynaptic interactions and signaling pathways). The two mechanisms should not be considered entirely independent as they are likely influencing each other. For example, alterations in synapse differentiation will also affect VGCC expression with further consequences on neuronal excitability and synaptic transmission

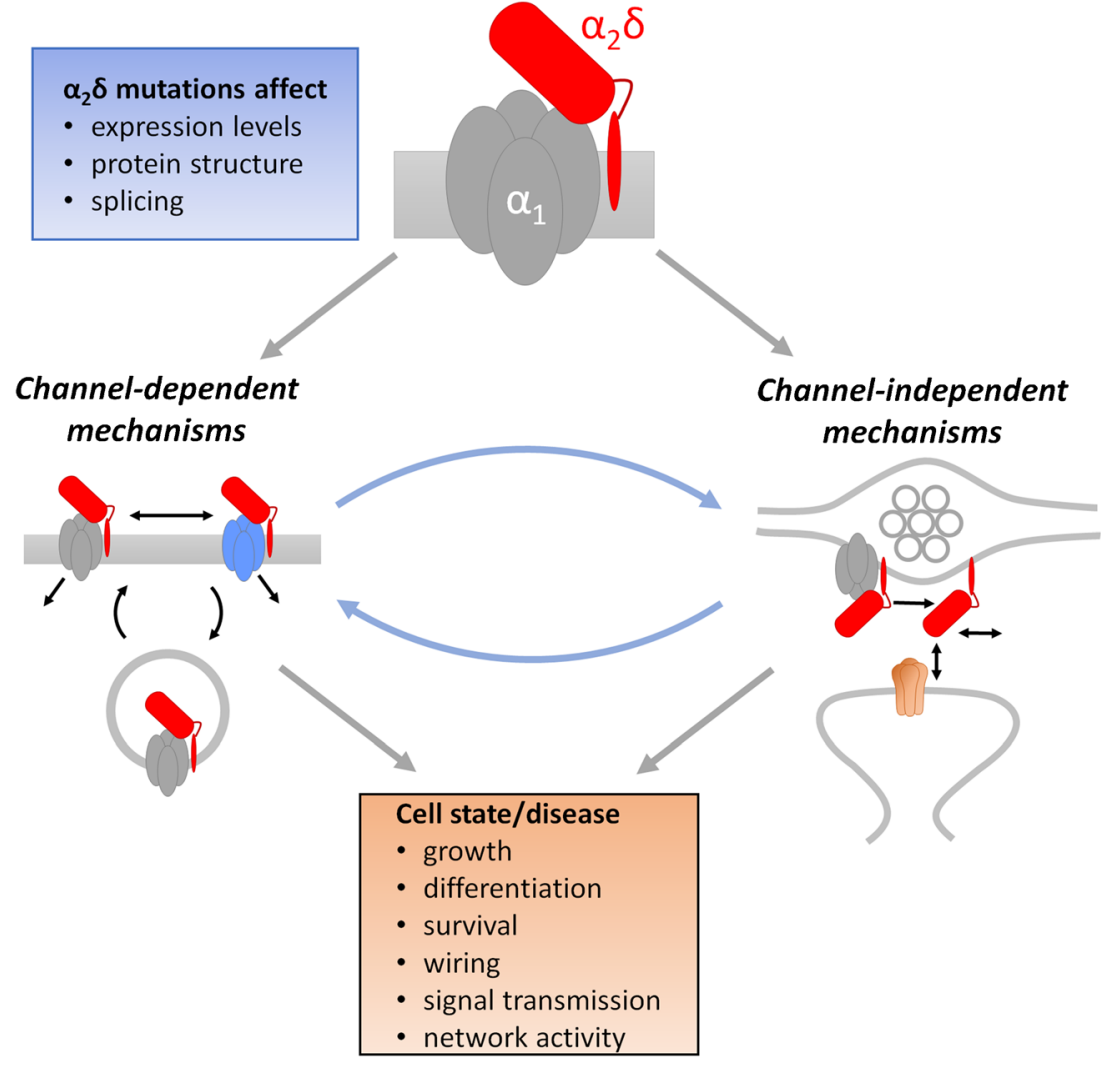

mutations may affect channel-dependent and channelindependent functions simultaneously or separately. Homology modeling based on an $\alpha_{2} \delta-1$ cryo-EM structure $[126,135]$ revealed that inclusion of single spliced exon 23 in $\alpha_{2} \delta$-2 resulted in the formation of an extra loop disrupting an $\alpha$-helix [40] (Fig. 4a). Hence, inclusion of this exon prevents the trans-synaptic recruitment of postsynaptic $\mathrm{GABA}_{\mathrm{A}}$ receptors. Since, based on the predicted structure, the region of the relevant exon is facing away from the channel into the synaptic cleft, it is conceivable that such structural alterations affect specific protein-protein interactions without modulating the calcium channel. Channel-independent structural interactions are supported by a very recent observation in our laboratory. While the integrity of the MIDAS motif in $\alpha_{2} \delta$ subunits was shown to be required for functional membrane expression of the channel complex [14, 48, 97], expression of MIDAS mutants could not rescue the accumulation of synaptic proteins in $\alpha_{2} \delta$ subunit triple knockout neurons [97].

The consequences of missense point mutations on channeldependent and channel-independent functions are not that easily predictable without detailed experimental evidence. In theory, missense mutations may alter the entire structure of $\alpha_{2} \delta$ proteins. Moreover, single missense mutations may also affect the interaction of $\alpha_{2} \delta$ subunits with the channel itself or with extracellular or trans-synaptic interaction partners. Here, we used structure-homology modeling (see Fig. 4) to predict the consequences of previously identified potentially autism- causing mutations in $\alpha_{2} \delta-1$ and $\alpha_{2} \delta-3$. While the p.Arg351Thr mutation may severely alter protein structure (see above), modeling of a specific mutation in $\alpha_{2} \delta-3$ (p.Ala917Thr) [42] provides an indication that even subtle changes may alter specific interactions. The location of p.Ala917Thr in the predicted structure of $\alpha_{2} \delta-3$ is a potential site for protein-protein interaction, partly facing towards the channel $\alpha_{1}$ subunit and partly facing to the extracellular side (Fig. 4b). Homology modeling does not suggest strong effects of this amino acid substitution on the overall structure. However, slight alterations in the surface electrostatic potential and hence surface hydrophobicity may suffice to influence the stability with specific inter-channel-complex interactions or components of the extracellular matrix. Considering ASD, one may speculate that an altered surface structure may influence the weak and dynamic interaction with synaptic cell adhesion molecules, for example neurexins [10], thereby affecting both channel and synaptic functions. We also modeled the potential consequences of an $\alpha_{2} \delta$-1 frameshift mutation likely causing epilepsy (p.Val875fs) [44]. While it is possible that altered mRNA may already trigger nonsense-mediated mRNA decay, an actually translated $\alpha_{2} \delta-1$ p.Val 875 fs protein may be functionally affected in two ways: first, the lack of the $\delta$ peptide and membrane anchoring will affect the stability of its membrane localization and hence channel interaction, and second, the frameshift not only deletes a large portion of the $\mathrm{C}$-terminal end of the protein including the entire $\delta$ peptide 
but also introduces a sequence stretch of 36 amino acids which will likely interfere with potential remaining protein-protein interactions (Fig. 4c). Hence and considering that the p.Val875fs mutation was found in epileptic patients, it seems consistent with the hypothesis that its pathophysiology may be mediated partly by channel-dependent functions influencing neuronal excitability and/or synaptic transmission.

\section{Future perspectives}

Over the last couple of years, the number of disease associations of $\alpha_{2} \delta$ genes and proteins has been steadily increasing. The multitude of distinct neurological and neuropsychiatric disorders likely involving $\alpha_{2} \delta$ proteins supports their important roles in neuronal functions (Fig. 5). Hence, on top of the existing drugs gabapentin and pregabalin, $\alpha_{2} \delta$ proteins may provide highly specific targets for future and novel paradigms in treating neurological disorders. This seems particularly promising when calcium channel-dependent as well as calcium channelindependent functions could be separately targeted. However, until then, several basic immanent research questions need to be further elucidated: first, although recent studies identified $\alpha_{2} \delta$ isoform-specific signaling pathways, the role of functional redundancy between the different isoforms is not yet understood. For example, while specific $\alpha_{2} \delta$ isoforms are clearly associated with distinct synaptic functions (see above), synapse deficiency in a presynaptic triple knockout phenotype can be rescued by the expression of each individual $\alpha_{2} \delta$ protein [97]. Second, the role of individual $\alpha_{2} \delta$ isoforms in neuron-type- and synapsetype-specific signaling mechanisms needs to be resolved. In the brain, $\alpha_{2} \delta$ proteins show an isoform-specific distribution pattern; however, this pattern shows considerable overlap and at least three isoforms can be simultaneously expressed in a single neuron. Hence, understanding neuron- and synapse-type specificity in $\alpha_{2} \delta$ protein functions will become increasingly important. For example, the extremely low abundance of $\alpha_{2} \delta-4$ in the brain may suggest the specific expression of this isoform in a lowly abundant neuronal cell type. Third, the definitive distinction between calcium channel-dependent and calcium channel-independent functions is until today an experimental challenge. Several recent studies identified $\alpha_{2} \delta$-specific signaling pathways and protein-protein interactions (e.g. BK channel and NMDAR). Yet, in neurons, multiple calcium channel types are ubiquitously expressed and critically involved in basic signaling functions. Consequentially, malfunctioning $\alpha_{2} \delta$ proteins are likely to also affect calcium channel functions. Fourth, $\alpha_{2} \delta$ proteins are emerging as novel and critical trans-synaptic organizing molecules, which may provide a missing link in understanding synapse formation and differentiation. It will be critical to identify their specific trans-synaptic mode of action including potential extracellular or presynaptic and postsynaptic interaction partners. Finally, cryo-EM analysis provided first insights into the structural organization of $\alpha_{2} \delta$ subunits, but until today, our understanding of neuronal $\alpha_{2} \delta$ proteins depends on structure-homology modeling based on the skeletal muscle calcium channel complex. In neurons, the actual structural organization of $\alpha_{2} \delta$ proteins may depend on their specific calcium channel associations and their potential extracellular and transsynaptic interactions.

Taking together, $\alpha_{2} \delta$ proteins are critical neuronal signaling proteins involved in a variety of cellular and synaptic mechanisms and altered function may cause or mediate neurological disorders. Future research efforts in studying their specific neuronal roles will help in understanding the pathophysiology of associated disorders and may open the way for the development of novel therapeutic paradigms.

Acknowledgments Open access funding provided by Austrian Science Fund (FWF). This work is part of the $\mathrm{PhD}$ thesis of C.A.

Funding information This work was supported by the Austrian Science Fund (FWF) grants F44150 and DOC30-B30 (G.J.O.).

\section{Compliance with ethical standards}

Conflict of interest The authors declare that they have no conflict of interest.

Open Access This article is licensed under a Creative Commons Attribution 4.0 International License, which permits use, sharing, adaptation, distribution and reproduction in any medium or format, as long as you give appropriate credit to the original author(s) and the source, provide a link to the Creative Commons licence, and indicate if changes were made. The images or other third party material in this article are included in the article's Creative Commons licence, unless indicated otherwise in a credit line to the material. If material is not included in the article's Creative Commons licence and your intended use is not permitted by statutory regulation or exceeds the permitted use, you will need to obtain permission directly from the copyright holder. To view a copy of this licence, visit http://creativecommons.org/licenses/by/4.0/.

\section{References}

1. Alvarez-Laviada A, Kadurin I, Senatore A, Chiesa R, Dolphin AC (2014) The inhibition of functional expression of calcium channels by prion protein demonstrates competition with alpha2delta for GPI-anchoring pathways. Biochem J 458:365-374. https://doi. org/10.1042/BJ20131405

2. Anantharaman V, Aravind L (2000) Cache - a signaling domain common to animal $\mathrm{Ca}(2+)$-channel subunits and a class of prokaryotic chemotaxis receptors. Trends Biochem Sci 25:535-537. https://doi.org/10.1016/s0968-0004(00)01672-8

3. Andrade A, Brennecke A, Mallat S, Brown J, Gomez-Rivadeneira J, Czepiel N, Londrigan L (2019) Genetic associations between voltage-gated calcium channels and psychiatric disorders. Int J Mol Sci:20. https://doi.org/10.3390/ijms20143537

4. Ba-Abbad R, Arno G, Carss K, Stirrups K, Penkett CJ, Moore AT, Michaelides M, Raymond FL, Webster AR, Holder GE (2016) Mutations in CACNA2D4 cause distinctive retinal dysfunction 
in humans. Ophthalmology 123:668-671 e662. https://doi.org/10. 1016/j.ophtha.2015.09.045

5. Beeson KA, Beeson R, Westbrook GL, Schnell E (2020) Alpha2delta-2 protein controls structure and function at the cerebellar climbing fiber synapse. J Neurosci 40:2403-2415. https:// doi.org/10.1523/JNEUROSCI.1514-19.2020

6. Berman HM, Westbrook J, Feng Z, Gilliland G, Bhat TN, Weissig H, Shindyalov IN, Bourne PE (2000) The Protein Data Bank. Nucleic Acids Res 28:235-242. https://doi.org/10.1093/nar/28.1. 235

7. Bikbaev A, Ciuraszkiewicz A, Heck J, Klatt O, Freund R, Mitlohner J, Lacalle SE, Sun M, Repetto D, Frischknecht R, Rohlmann A, Missler M, Obermair GJ, Di Biase V, Heine M (2020) Auxiliary alpha2delta1 and alpha2delta3 subunits of calcium channels drive excitatory and inhibitory neuronal network development. J Neurosci. https://doi.org/10.1523/JNEUROSCI. 1707-19.2020

8. Bourinet E, Francois A, Laffray S (2016) T-type calcium channels in neuropathic pain. Pain 157:S15-S22. https://doi.org/10.1097/j. pain.0000000000000469

9. Bowling H, Bhattacharya A, Zhang G, Lebowitz JZ, Alam D, Smith PT, Kirshenbaum K, Neubert TA, Vogel C, Chao MV, Klann E (2016) BONLAC: a combinatorial proteomic technique to measure stimulus-induced translational profiles in brain slices. Neuropharmacology 100:76-89. https://doi.org/10.1016/j. neuropharm.2015.07.017

10. Brockhaus J, Schreitmuller M, Repetto D, Klatt O, Reissner C, Elmslie K, Heine M, Missler M (2018) Alpha-neurexins together with alpha2delta-1 auxiliary subunits regulate $\mathrm{Ca}(2+)$ influx through Cav2.1 channels. J Neurosci 38:8277-8294. https://doi. org/10.1523/JNEUROSCI.0511-18.2018

11. Buraei Z, Yang J (2010) The $\beta$ subunit of voltage-gated Ca2+ channels. Physiol Rev 90:1461-1506. https://doi.org/10.1152/ physrev.00057.2009

12. Butler KM, Holt PJ, Milla SS, da Silva C, Alexander JJ, Escayg A (2018) Epileptic encephalopathy and cerebellar atrophy resulting from compound heterozygous CACNA2D2 variants. Case Rep Genet 2018:1-4. https://doi.org/10.1155/2018/6308283

13. Calderon-Rivera A, Andrade A, Hernandez-Hernandez O, Gonzalez-Ramirez R, Sandoval A, Rivera M, Gomora JC, Felix $R$ (2012) Identification of a disulfide bridge essential for structure and function of the voltage-gated $\mathrm{Ca}(2+)$ channel alpha(2)delta-1 auxiliary subunit. Cell Calcium 51:22-30. https://doi.org/10. 1016/j.ceca.2011.10.002

14. Canti C, Nieto-Rostro M, Foucault I, Heblich F, Wratten J, Richards MW, Hendrich J, Douglas L, Page KM, Davies A, Dolphin AC (2005) The metal-ion-dependent adhesion site in the Von Willebrand factor-a domain of alpha2delta subunits is key to trafficking voltage-gated $\mathrm{Ca} 2+$ channels. Proc Natl Acad Sci U S A 102:11230-11235. https://doi.org/10.1073/pnas. 0504183102

15. Cao Y, Sarria I, Fehlhaber KE, Kamasawa N, Orlandi C, James KN, Hazen JL, Gardner MR, Farzan M, Lee A, Baker S, Baldwin K, Sampath AP, Martemyanov KA (2015) Mechanism for selective synaptic wiring of rod photoreceptors into the retinal circuitry and its role in vision. Neuron 87:1248-1260. https://doi.org/10. 1016/j.neuron.2015.09.002

16. Caylor RC, Jin Y, Ackley BD (2013) The Caenorhabditis elegans voltage-gated calcium channel subunits UNC-2 and UNC-36 and the calcium-dependent kinase UNC-43/CaMKII regulate neuromuscular junction morphology. Neural Dev 8:10. https://doi.org/ 10.1186/1749-8104-8-10

17. Celli R, Santolini I, Guiducci M, van Luijtelaar G, Parisi P, Striano P, Gradini R, Battaglia G, Ngomba RT, Nicoletti F (2017) The alpha2delta subunit and absence epilepsy: beyond calcium channels? Curr Neuropharmacol 15:918-925. https://doi.org/10. 2174/1570159X15666170309105451

18. Chen J, Li L, Chen SR, Chen H, Xie JD, Sirrieh RE, MacLean DM, Zhang Y, Zhou MH, Jayaraman V, Pan HL (2018) The alpha2delta-1-NMDA receptor complex is critically involved in neuropathic pain development and gabapentin therapeutic actions. Cell Rep 22:2307-2321. https://doi.org/10.1016/j.celrep.2018.02. 021

19. Cordeira JW, Felsted JA, Teillon S, Daftary S, Panessiti M, Wirth J, Sena-Esteves M, Rios M (2014) Hypothalamic dysfunction of the thrombospondin receptor alpha2delta-1 underlies the overeating and obesity triggered by brain-derived neurotrophic factor deficiency. J Neurosci 34:554-565. https://doi.org/10.1523/ JNEUROSCI.1572-13.2014

20. Cottrell GS, Soubrane CH, Hounshell JA, Lin H, Owenson V, Rigby M, Cox PJ, Barker BS, Ottolini M, Ince S, Bauer CC, Perez-Reyes E, Patel MK, Stevens EB, Stephens GJ (2018) CACHD1 is an alpha2delta-like protein that modulates CaV3 voltage-gated calcium channel activity. J Neurosci 38:91869201. https://doi.org/10.1523/JNEUROSCI.3572-15.2018

21. Craig AM, Graf ER, Linhoff MW (2006) How to build a central synapse: clues from cell culture. Trends Neurosci 29:8-20. https:/ doi.org/10.1016/j.tins.2005.11.002

22. Cross-Disorder Group of the Psychiatric Genomics Consortium (2013) Identification of risk loci with shared effects on five major psychiatric disorders: a genome-wide analysis. Lancet 381:13711379. https://doi.org/10.1016/S0140-6736(12)62129-1

23. Dahimene S, Page KM, Kadurin I, Ferron L, Ho DY, Powell GT, Pratt WS, Wilson SW, Dolphin AC (2018) The alpha2delta-like protein Cachd 1 increases N-type calcium currents and cell surface expression and competes with alpha2delta-1. Cell Rep 25:1610 1621 e1615. https://doi.org/10.1016/j.celrep.2018.10.033

24. Davies A, Douglas L, Hendrich J, Wratten J, Tran Van Minh A, Foucault I, Koch D, Pratt WS, Saibil HR, Dolphin AC (2006) The calcium channel alpha2delta-2 subunit partitions with $\mathrm{CaV} 2.1$ into lipid rafts in cerebellum: implications for localization and function. J Neurosci 26:8748-8757. https://doi.org/10.1523/ JNEUROSCI.2764-06.2006

25. Davies A, Hendrich J, Van Minh AT, Wratten J, Douglas L, Dolphin AC (2007) Functional biology of the alpha(2)delta subunits of voltage-gated calcium channels. Trends Pharmacol Sci 28:220-228. https://doi.org/10.1016/j.tips.2007.03.005

26. Davies A, Kadurin I, Alvarez-Laviada A, Douglas L, NietoRostro M, Bauer CS, Pratt WS, Dolphin AC (2010) The alpha2delta subunits of voltage-gated calcium channels form GPI-anchored proteins, a posttranslational modification essential for function. Proc Natl Acad Sci U S A 107:1654-1659. https:// doi.org/10.1073/pnas.0908735107

27. De Jongh KS, Warner C, Catterall WA (1990) Subunits of purified calcium channels. Alpha 2 and delta are encoded by the same gene. J Biol Chem 265:14738-14741

28. De Rubeis S, He X, Goldberg AP, Poultney CS, Samocha K, Cicek AE, Kou Y, Liu L, Fromer M, Walker S, Singh T, Klei L, Kosmicki J, Shih-Chen F, Aleksic B, Biscaldi M, Bolton PF, Brownfeld JM, Cai J, Campbell NG, Carracedo A, Chahrour $\mathrm{MH}$, Chiocchetti AG, Coon H, Crawford EL, Curran SR, Dawson G, Duketis E, Fernandez BA, Gallagher L, Geller E, Guter SJ, Hill RS, Ionita-Laza J, Jimenz Gonzalez P, Kilpinen H, Klauck SM, Kolevzon A, Lee I, Lei I, Lei J, Lehtimaki T, Lin CF, Ma'ayan A, Marshall CR, McInnes AL, Neale B, Owen MJ, Ozaki N, Parellada M, Parr JR, Purcell S, Puura K, Rajagopalan D, Rehnstrom K, Reichenberg A, Sabo A, Sachse M, Sanders SJ, Schafer C, Schulte-Ruther M, Skuse D, Stevens C, Szatmari P, Tammimies K, Valladares O, Voran A, Li-San W, Weiss LA, Willsey AJ, Yu TW, Yuen RK, Study DDD, Homozygosity Mapping Collaborative for A, Consortium UK, 
Cook EH, Freitag CM, Gill M, Hultman CM, Lehner T, Palotie A, Schellenberg GD, Sklar P, State MW, Sutcliffe JS, Walsh CA, Scherer SW, Zwick ME, Barett JC, Cutler DJ, Roeder K, Devlin B, Daly MJ, Buxbaum JD (2014) Synaptic, transcriptional and chromatin genes disrupted in autism. Nature 515:209-215. https://doi.org/10.1038/nature13772

29. De Sevilla Muller LP, Liu J, Solomon A, Rodriguez A, Brecha NC (2013) Expression of voltage-gated calcium channel alpha(2)delta(4) subunits in the mouse and rat retina. J Comp Neurol 521:2486-2501. https://doi.org/10.1002/cne.23294

30. Deng M, Chen SR, Chen H, Pan HL (2019) Alpha2delta-1-bound $\mathrm{N}$-methyl-D-aspartate receptors mediate morphine-induced hyperalgesia and analgesic tolerance by potentiating glutamatergic input in rodents. Anesthesiology 130:804-819. https://doi.org/10. 1097/ALN.0000000000002648

31. Dolphin AC (2012) Calcium channel auxiliary alpha2delta and beta subunits: trafficking and one step beyond. Nat Rev Neurosci 13:542-555. https://doi.org/10.1038/nrn3311

32. Dolphin AC (2018) Voltage-gated calcium channel alpha 2delta subunits: an assessment of proposed novel roles. F1000Res 7. https://doi.org/10.12688/f1000research.16104.1

33. Dunn EC, Wiste A, Radmanesh F, Almli LM, Gogarten SM, Sofer T, Faul JD, Kardia SL, Smith JA, Weir DR, Zhao W, Soare TW, Mirza SS, Hek K, Tiemeier H, Goveas JS, Sarto GE, Snively BM, Cornelis M, Koenen KC, Kraft P, Purcell S, Ressler KJ, Rosand J, Wassertheil-Smoller S, Smoller JW (2016) Genome-wide association study (GWAS) and genome-wide by environment interaction study (GWEIS) of depressive symptoms in African American and Hispanic/Latina women. Depress Anxiety 33:265-280. https://doi.org/10.1002/da.22484

34. Edvardson S, Oz S, Abulhijaa FA, Taher FB, Shaag A, Zenvirt S, Dascal N, Elpeleg O (2013) Early infantile epileptic encephalopathy associated with a high voltage gated calcium channelopathy. J Med Genet 50:118-123. https://doi.org/10.1136/jmedgenet2012-101223

35. Eroglu C, Allen NJ, Susman MW, O'Rourke NA, Park CY, Ozkan E, Chakraborty C, Mulinyawe SB, Annis DS, Huberman AD, Green EM, Lawler J, Dolmetsch R, Garcia KC, Smith SJ, Luo ZD, Rosenthal A, Mosher DF, Barres BA (2009) Gabapentin receptor alpha2delta-1 is a neuronal thrombospondin receptor responsible for excitatory CNS synaptogenesis. Cell 139:380-392. https://doi.org/10.1016/j.cell.2009.09.025

36. Felix R, Gurnett CA, De Waard M, Campbell KP (1997) Dissection of functional domains of the voltage-dependent $\mathrm{Ca} 2+$ channel alpha2delta subunit. J Neurosci 17:6884-6891

37. Fell B, Eckrich S, Blum K, Eckrich T, Hecker D, Obermair GJ, Munkner S, Flockerzi V, Schick B, Engel J (2016) Alpha2delta2 controls the function and trans-synaptic coupling of Cav1.3 channels in mouse inner hair cells and is essential for normal hearing. $\mathrm{J}$ Neurosci 36:11024-11036. https://doi.org/10.1523/JNEUROSCI. 3468-14.2016

38. Gamlin CR, Yu WQ, Wong ROL, Hoon M (2018) Assembly and maintenance of GABAergic and glycinergic circuits in the mammalian nervous system. Neural Dev 13:12. https://doi.org/10. 1186/s13064-018-0109-6

39. Geisler S, Schopf CL, Obermair GJ (2015) Emerging evidence for specific neuronal functions of auxiliary calcium channel alpha(2)delta subunits. Gen Physiol Biophys 34:105-118. https://doi.org/10.4149/gpb_2014037

40. Geisler S, Schopf CL, Stanika R, Kalb M, Campiglio M, Repetto D, Traxler L, Missler M, Obermair GJ (2019) Presynaptic alpha2delta-2 calcium channel subunits regulate postsynaptic GABAA receptor abundance and axonal wiring. J Neurosci 39: 2581-2605. https://doi.org/10.1523/JNEUROSCI.2234-18.2019

41. Girirajan S, Dennis MY, Baker C, Malig M, Coe BP, Campbell CD, Mark K, Vu TH, Alkan C, Cheng Z, Biesecker LG, Bernier
R, Eichler EE (2013) Refinement and discovery of new hotspots of copy-number variation associated with autism spectrum disorder. Am J Hum Genet 92:221-237. https://doi.org/10.1016/j.ajhg. 2012.12.016

42. Guo H, Wang T, Wu H, Long M, Coe BP, Li H, Xun G, Ou J, Chen B, Duan G, Bai T, Zhao N, Shen Y, Li Y, Wang Y, Zhang Y, Baker C, Liu Y, Pang N, Huang L, Han L, Jia X, Liu C, Ni H, Yang X, Xia L, Chen J, Shen L, Li Y, Zhao R, Zhao W, Peng J, Pan Q, Long Z, Su W, Tan J, Du X, Ke X, Yao M, Hu Z, Zou X, Zhao J, Bernier RA, Eichler EE, Xia K (2018) Inherited and multiple de novo mutations in autism/developmental delay risk genes suggest a multifactorial model. Mol Autism 9:64. https://doi.org/ 10.1186/s13229-018-0247-z

43. Heyes S, Pratt WS, Rees E, Dahimene S, Ferron L, Owen MJ, Dolphin AC (2015) Genetic disruption of voltage-gated calcium channels in psychiatric and neurological disorders. Prog Neurobiol 134:36-54. https://doi.org/10.1016/j.pneurobio.2015. 09.002

44. Hino-Fukuyo N, Kikuchi A, Arai-Ichinoi N, Niihori T, Sato R, Suzuki T, Kudo H, Sato Y, Nakayama T, Kakisaka Y, Kubota Y, Kobayashi T, Funayama R, Nakayama K, Uematsu M, Aoki Y, Haginoya K, Kure S (2015) Genomic analysis identifies candidate pathogenic variants in 9 of 18 patients with unexplained West syndrome. Hum Genet 134:649-658. https://doi.org/10.1007/ s00439-015-1553-6

45. Hobom M, Dai S, Marais E, Lacinova L, Hofmann F, Klugbauer $N$ (2000) Neuronal distribution and functional characterization of the calcium channel alpha2delta-2 subunit. Eur J Neurosci 12: 1217-1226. https://doi.org/10.1046/j.1460-9568.2000.01009.x

46. Hooper NM (2001) Determination of glycosylphosphatidylinositol membrane protein anchorage. Proteomics 1:748-755. https://doi.org/10.1002/1615-9861(200106)1: 6<748::AID-PROT748>3.0.CO;2-T

47. Hoover KM, Gratz SJ, Qi N, Herrmann KA, Liu Y, PerryRichardson JJ, Vanderzalm PJ, O'Connor-Giles KM, Broihier HT (2019) The calcium channel subunit alpha2delta-3 organizes synapses via an activity-dependent and autocrine BMP signaling pathway. Nat Commun 10:5575. https://doi.org/10.1038/s41467019-13165-7

48. Hoppa MB, Lana B, Margas W, Dolphin AC, Ryan TA (2012) Alpha2delta expression sets presynaptic calcium channel abundance and release probability. Nature 486:122-125. https://doi. org/10.1038/nature11033

49. Howard DM, Adams MJ, Clarke TK, Hafferty JD, Gibson J, Shirali M, Coleman JRI, Hagenaars SP, Ward J, Wigmore EM, Alloza C, Shen X, Barbu MC, Xu EY, Whalley HC, Marioni RE, Porteous DJ, Davies G, Deary IJ, Hemani G, Berger K, Teismann H, Rawal R, Arolt V, Baune BT, Dannlowski U, Domschke K, Tian C, Hinds DA, Me Research T, Major Depressive Disorder Working Group of the Psychiatric Genomics C, Trzaskowski M, Byrne EM, Ripke S, Smith DJ, Sullivan PF, Wray NR, Breen G, Lewis CM, McIntosh AM (2019) Genome-wide meta-analysis of depression identifies 102 independent variants and highlights the importance of the prefrontal brain regions. Nat Neurosci 22:343352. https://doi.org/10.1038/s41593-018-0326-7

50. Ikeda M, Shimasaki A, Takahashi A, Kondo K, Saito T, Kawase K, Esaki K, Otsuka Y, Mano K, Kubo M, Iwata N (2016) Genome-wide environment interaction between depressive state and stressful life events. J Clin Psychiatry 77:e29-e30. https:// doi.org/10.4088/JCP.15110127

51. Iossifov I, O'Roak BJ, Sanders SJ, Ronemus M, Krumm N, Levy D, Stessman HA, Witherspoon KT, Vives L, Patterson KE, Smith JD, Paeper B, Nickerson DA, Dea J, Dong S, Gonzalez LE, Mandell JD, Mane SM, Murtha MT, Sullivan CA, Walker MF, Waqar Z, Wei L, Willsey AJ, Yamrom B, Lee YH, Grabowska E, Dalkic E, Wang Z, Marks S, Andrews P, Leotta A, Kendall J, 
Hakker I, Rosenbaum J, Ma B, Rodgers L, Troge J, Narzisi G, Yoon S, Schatz MC, Ye K, McCombie WR, Shendure J, Eichler EE, State MW, Wigler M (2014) The contribution of de novo coding mutations to autism spectrum disorder. Nature 515:216 221. https://doi.org/10.1038/nature13908

52. Iossifov I, Ronemus M, Levy D, Wang Z, Hakker I, Rosenbaum J, Yamrom B, Lee YH, Narzisi G, Leotta A, Kendall J, Grabowska E, Ma B, Marks S, Rodgers L, Stepansky A, Troge J, Andrews P, Bekritsky M, Pradhan K, Ghiban E, Kramer M, Parla J, Demeter R, Fulton LL, Fulton RS, Magrini VJ, Ye K, Darnell JC, Darnell RB, Mardis ER, Wilson RK, Schatz MC, McCombie WR, Wigler M (2012) De novo gene disruptions in children on the autistic spectrum. Neuron 74:285-299. https://doi.org/10.1016/j.neuron.2012.04.009

53. Kadurin I, Rothwell SW, Lana B, Nieto-Rostro M, Dolphin AC (2017) LRP1 influences trafficking of N-type calcium channels via interaction with the auxiliary alpha2delta-1 subunit. Sci Rep 7:43802. https://doi.org/10.1038/srep43802

54. Kerov V, Laird JG, Joiner ML, Knecht S, Soh D, Hagen J, Gardner SH, Gutierrez W, Yoshimatsu T, Bhattarai S, Puthussery T, Artemyev NO, Drack AV, Wong RO, Baker SA, Lee A (2018) Alpha2delta-4 is required for the molecular and structural organization of rod and cone photoreceptor synapses. J Neurosci 38:6145-6160. https://doi.org/10.1523/JNEUROSCI. 3818-16.2018

55. Klassen T, Davis C, Goldman A, Burgess D, Chen T, Wheeler D, McPherson J, Bourquin T, Lewis L, Villasana D, Morgan M, Muzny D, Gibbs R, Noebels J (2011) Exome sequencing of ion channel genes reveals complex profiles confounding personal risk assessment in epilepsy. Cell 145:1036-1048. https://doi.org/10. 1016/j.cell.2011.05.025

56. Klugbauer N, Lacinova L, Marais E, Hobom M, Hofmann F (1999) Molecular diversity of the calcium channel alpha2delta subunit. J Neurosci 19:684-691

57. Klugbauer N, Marais E, Hofmann F (2003) Calcium channel alpha2delta subunits: differential expression, function, and drug binding. J Bioenerg Biomembr 35:639-647. https://doi.org/10. 1023/b:jobb.0000008028.41056.58

58. Knoflach D, Kerov V, Sartori SB, Obermair GJ, Schmuckermair C, Liu X, Sothilingam V, Garcia Garrido M, Baker SA, Glosmann M, Schicker K, Seeliger M, Lee A, Koschak A (2013) Cav1.4 IT mouse as model for vision impairment in human congenital stationary night blindness type 2. Channels (Austin) 7:503-513. https://doi.org/10.4161/chan.26368

59. Kurshan PT, Oztan A, Schwarz TL (2009) Presynaptic alpha2delta-3 is required for synaptic morphogenesis independent of its Ca2+-channel functions. Nat Neurosci 12:1415-1423. https://doi.org/10.1038/nn.2417

60. Lana B, Schlick B, Martin S, Pratt WS, Page KM, Goncalves L, Rahman W, Dickenson AH, Bauer CS, Dolphin AC (2014) Differential upregulation in DRG neurons of an alpha2delta-1 splice variant with a lower affinity for gabapentin after peripheral sensory nerve injury. Pain 155:522-533. https://doi.org/10.1016/j. pain.2013.12.001

61. Lardi-Studler B, Fritschy JM (2007) Matching of pre- and postsynaptic specializations during synaptogenesis. Neuroscientist 13: 115-126. https://doi.org/10.1177/1073858406296803

62. Li J, Yoshikawa A, Brennan MD, Ramsey TL, Meltzer HY (2018) Genetic predictors of antipsychotic response to lurasidone identified in a genome wide association study and by schizophrenia risk genes. Schizophr Res 192:194-204. https://doi.org/10.1016/j. schres.2017.04.009

63. Liu J, Chen J, Perrone-Bizzozero NI, Turner JA, Calhoun VD (2018) Regional enrichment analyses on genetic profiles for schizophrenia and bipolar disorder. Schizophr Res 192:240-246. https://doi.org/10.1016/j.schres.2017.04.033
64. Ma H, Chen SR, Chen H, Li L, Li DP, Zhou JJ, Pan HL (2018) Alpha2delta-1 is essential for sympathetic output and NMDA receptor activity potentiated by angiotensin II in the hypothalamus. J Neurosci 38:6388-6398. https://doi.org/10.1523/JNEUROSCI. 0447-18.2018

65. Ma H, Chen SR, Chen H, Zhou JJ, Li DP, Pan HL (2018) Alpha2delta-1 couples to NMDA receptors in the hypothalamus to sustain sympathetic vasomotor activity in hypertension. J Physiol 596:4269-4283. https://doi.org/10.1113/JP276394

66. Malhotra D, Sebat J (2012) CNVs: harbingers of a rare variant revolution in psychiatric genetics. Cell 148:1223-1241. https:// doi.org/10.1016/j.cell.2012.02.039

67. Meda SA, Ruano G, Windemuth A, O'Neil K, Berwise C, Dunn SM, Boccaccio LE, Narayanan B, Kocherla M, Sprooten E, Keshavan MS, Tamminga CA, Sweeney JA, Clementz BA, Calhoun VD, Pearlson GD (2014) Multivariate analysis reveals genetic associations of the resting default mode network in psychotic bipolar disorder and schizophrenia. Proc Natl Acad Sci U S A 111:E2066-E2075. https://doi.org/10.1073/pnas.1313093111

68. Mefford HC, Yendle SC, Hsu C, Cook J, Geraghty E, McMahon JM, Eeg-Olofsson O, Sadleir LG, Gill D, Ben-Zeev B, LermanSagie T, Mackay M, Freeman JL, Andermann E, Pelakanos JT, Andrews I, Wallace G, Eichler EE, Berkovic SF, Scheffer IE (2011) Rare copy number variants are an important cause of epileptic encephalopathies. Ann Neurol 70:974-985. https://doi.org/ 10.1002/ana.22645

69. Molecular Operating Environment (MOE), 2018.03; Chemical Computing Group ULC, 1010 Sherbooke St. West, Suite \#910, Montreal, QC, Canada, H3A 2R7

70. Moons T, De Hert M, Gellens E, Gielen L, Sweers K, Jacqmaert S, van Winkel R, Vandekerckhove P, Claes S (2016) Genetic evaluation of schizophrenia using the Illumina HumanExome Chip. PLoS One 11:e0150464. https://doi.org/10.1371/journal.pone.0150464

71. Muller CS, Haupt A, Bildl W, Schindler J, Knaus HG, Meissner M, Rammner B, Striessnig J, Flockerzi V, Fakler B, Schulte U (2010) Quantitative proteomics of the Cav2 channel nanoenvironments in the mammalian brain. Proc Natl Acad Sci U S A 107:14950-14957. https://doi.org/10.1073/pnas.1005940107

72. Neely GG, Hess A, Costigan M, Keene AC, Goulas S, Langeslag M, Griffin RS, Belfer I, Dai F, Smith SB, Diatchenko L, Gupta V, Xia CP, Amann S, Kreitz S, Heindl-Erdmann C, Wolz S, Ly CV, Arora S, Sarangi R, Dan D, Novatchkova M, Rosenzweig M, Gibson DG, Truong D, Schramek D, Zoranovic T, Cronin SJ, Angjeli B, Brune K, Dietzl G, Maixner W, Meixner A, Thomas W, Pospisilik JA, Alenius M, Kress M, Subramaniam S, Garrity PA, Bellen HJ, Woolf CJ, Penninger JM (2010) A genome-wide Drosophila screen for heat nociception identifies alpha2delta3 as an evolutionarily conserved pain gene. Cell 143:628-638. https:// doi.org/10.1016/j.cell.2010.09.047

73. Nieto-Rostro M, Ramgoolam K, Pratt WS, Kulik A, Dolphin AC (2018) Ablation of alpha2delta-1 inhibits cell-surface trafficking of endogenous N-type calcium channels in the pain pathway in vivo. Proc Natl Acad Sci U S A 115:E12043-E12052. https:// doi.org/10.1073/pnas.1811212115

74. Obermair GJ, Kugler G, Baumgartner S, Tuluc P, Grabner M, Flucher BE (2005) The Ca2+ channel alpha2delta-1 subunit determines $\mathrm{Ca} 2+$ current kinetics in skeletal muscle but not targeting of alpha1S or excitation-contraction coupling. J Biol Chem 280: 2229-2237. https://doi.org/10.1074/jbc.M411501200

75. Obermair GJ, Tuluc P, Flucher BE (2008) Auxiliary Ca(2+) channel subunits: lessons learned from muscle. Curr Opin Pharmacol 8:311-318. https://doi.org/10.1016/j.coph.2008.01.008

76. Okbay A, Baselmans BM, De Neve JE, Turley P, Nivard MG, Fontana MA, Meddens SF, Linner RK, Rietveld CA, Derringer J, Gratten J, Lee JJ, Liu JZ, de Vlaming R, Ahluwalia TS, Buchwald J, Cavadino A, Frazier-Wood AC, Furlotte NA, Garfield V, Geisel 
MH, Gonzalez JR, Haitjema S, Karlsson R, van der Laan SW, Ladwig KH, Lahti J, van der Lee SJ, Lind PA, Liu T, Matteson L, Mihailov E, Miller MB, Minica CC, Nolte IM, MookKanamori D, van der Most PJ, Oldmeadow C, Qian Y, Raitakari O, Rawal R, Realo A, Rueedi R, Schmidt B, Smith AV, Stergiakouli E, Tanaka T, Taylor K, Thorleifsson G, Wedenoja J, Wellmann J, Westra HJ, Willems SM, Zhao W, LifeLines Cohort S, Amin N, Bakshi A, Bergmann S, Bjornsdottir G, Boyle PA, Cherney S, Cox SR, Davies G, Davis OS, Ding J, Direk N, Eibich P, Emeny RT, Fatemifar G, Faul JD, Ferrucci L, Forstner AJ, Gieger C, Gupta R, Harris TB, Harris JM, Holliday EG, Hottenga JJ, De Jager PL, Kaakinen MA, Kajantie E, Karhunen V, Kolcic I, Kumari M, Launer LJ, Franke L, Li-Gao R, Liewald DC, Koini M, Loukola A, Marques-Vidal P, Montgomery GW, Mosing MA, Paternoster L, Pattie A, Petrovic KE, Pulkki-Raback L, Quaye L, Raikkonen K, Rudan I, Scott RJ, Smith JA, Sutin AR, Trzaskowski M, Vinkhuyzen AE, Yu L, Zabaneh D, Attia JR, Bennett DA, Berger K, Bertram L, Boomsma DI, Snieder H, Chang SC, Cucca F, Deary IJ, van Duijn CM, Eriksson JG, Bultmann U, de Geus EJ, Groenen PJ, Gudnason V, Hansen T, Hartman CA, Haworth CM, Hayward C, Heath AC, Hinds DA, Hypponen E, Iacono WG, Jarvelin MR, Jockel KH, Kaprio J, Kardia SL, Keltikangas-Jarvinen L, Kraft P, Kubzansky LD, Lehtimaki T, Magnusson PK, Martin NG, McGue M, Metspalu A, Mills M, de Mutsert R, Oldehinkel AJ, Pasterkamp G, Pedersen NL, Plomin R, Polasek O, Power C, Rich SS, Rosendaal FR, den Ruijter HM, Schlessinger D, Schmidt H, Svento R, Schmidt R, Alizadeh BZ, Sorensen TI, Spector TD, Starr JM, Stefansson K, Steptoe A, Terracciano A, Thorsteinsdottir U, Thurik AR, Timpson NJ, Tiemeier H, Uitterlinden AG, Vollenweider P, Wagner GG, Weir DR, Yang J, Conley DC, Smith GD, Hofman A, Johannesson M, Laibson DI, Medland SE, Meyer MN, Pickrell JK, Esko T, Krueger RF, Beauchamp JP, Koellinger PD, Benjamin DJ, Bartels M, Cesarini D (2016) Genetic variants associated with subjective well-being, depressive symptoms, and neuroticism identified through genome-wide analyses. Nat Genet 48:624-633. https://doi.org/ 10.1038/ng.3552

77. Pan B, Guo Y, Wu HE, Park J, Trinh VN, Luo ZD, Hogan QH (2016) Thrombospondin-4 divergently regulates voltage-gated $\mathrm{Ca} 2+$ channel subtypes in sensory neurons after nerve injury. Pain 157:2068-2080. https://doi.org/10.1097/j.pain.0000000000000612

78. Park J, Yu YP, Zhou CY, Li KW, Wang D, Chang E, Kim DS, Vo B, Zhang X, Gong N, Sharp K, Steward O, Vitko I, Perez-Reyes E, Eroglu C, Barres B, Zaucke F, Feng G, Luo ZD (2016) Central mechanisms mediating thrombospondin-4-induced pain states. $\mathrm{J}$ Biol Chem 291:13335-13348. https://doi.org/10.1074/jbc.M116. 723478

79. Peng J, Kim MJ, Cheng D, Duong DM, Gygi SP, Sheng M (2004) Semiquantitative proteomic analysis of rat forebrain postsynaptic density fractions by mass spectrometry. J Biol Chem 279:2100321011. https://doi.org/10.1074/jbc.M400103200

80. Pietrobon D (2013) Calcium channels and migraine. Biochim Biophys Acta 1828:1655-1665. https://doi.org/10.1016/j. bbamem.2012.11.012

81. Pippucci T, Parmeggiani A, Palombo F, Maresca A, Angius A, Crisponi L, Cucca F, Liguori R, Valentino ML, Seri M, Carelli V (2013) A novel null homozygous mutation confirms CACNA2D2 as a gene mutated in epileptic encephalopathy. PLoS One 8: e82154. https://doi.org/10.1371/journal.pone.0082154

82. Pirone A, Kurt S, Zuccotti A, Ruttiger L, Pilz P, Brown DH, Franz C, Schweizer M, Rust MB, Rubsamen R, Friauf E, Knipper M, Engel J (2014) Alpha2delta3 is essential for normal structure and function of auditory nerve synapses and is a novel candidate for auditory processing disorders. J Neurosci 34:434 445. https://doi. org/10.1523/JNEUROSCI.3085-13.2014
83. Prabhu S, Pe'er I (2012) Ultrafast genome-wide scan for SNP-SNP interactions in common complex disease. Genome Res 22:2230 2240. https://doi.org/10.1101/gr.137885.112

84. Punetha J, Karaca E, Gezdirici A, Lamont RE, Pehlivan D, Marafi D, Appendino JP, Hunter JV, Akdemir ZC, Fatih JM, Jhangiani SN, Gibbs RA, Innes AM, Posey JE, Lupski JR (2019) Biallelic CACNA2D2 variants in epileptic encephalopathy and cerebellar atrophy. Ann Clin Transl Neurol 6:1395-1406. https://doi.org/10. 1002/acn3.50824

85. Purcell SM, Moran JL, Fromer M, Ruderfer D, Solovieff N, Roussos P, O'Dushlaine C, Chambert K, Bergen SE, Kahler A, Duncan L, Stahl E, Genovese G, Fernandez E, Collins MO, Komiyama NH, Choudhary JS, Magnusson PK, Banks E, Shakir K, Garimella K, Fennell T, DePristo M, Grant SG, Haggarty SJ, Gabriel S, Scolnick EM, Lander ES, Hultman CM, Sullivan PF, McCarroll SA, Sklar P (2014) A polygenic burden of rare disruptive mutations in schizophrenia. Nature 506:185-190. https://doi.org/10.1038/nature12975

86. Qin L, Actor-Engel HS, Woo MS, Shakil F, Chen YW, Cho S, Aoki C (2019) An increase of excitatory-to-inhibitory synaptic balance in the contralateral cortico-striatal pathway underlies improved stroke recovery in BDNF Val66Met SNP mice. Neurorehabil Neural Repair 33:989-1002. https://doi.org/10. $1177 / 1545968319872997$

87. Qin N, Olcese R, Stefani E, Birnbaumer L (1998) Modulation of human neuronal alpha 1E-type calcium channel by alpha 2 deltasubunit. Am J Physiol 274:C1324-C1331. https://doi.org/10. 1152/ajpcell.1998.274.5.C1324

88. Qin N, Yagel S, Momplaisir ML, Codd EE, D'Andrea MR (2002) Molecular cloning and characterization of the human voltagegated calcium channel alpha(2)delta-4 subunit. Mol Pharmacol 62:485-496. https://doi.org/10.1124/mol.62.3.485

89. Rajakulendran S, Hanna MG (2016) The role of calcium channels in epilepsy. Cold Spring Harb Perspect Med 6:a022723. https:// doi.org/10.1101/cshperspect.a022723

90. Risher WC, Kim N, Koh S, Choi JE, Mitev P, Spence EF, Pilaz LJ, Wang D, Feng G, Silver DL, Soderling SH, Yin HH, Eroglu C (2018) Thrombospondin receptor alpha2delta-1 promotes synaptogenesis and spinogenesis via postsynaptic Rac1. J Cell Biol 217: 3747-3765. https://doi.org/10.1083/jcb.201802057

91. Robinson P, Etheridge S, Song L, Shah R, Fitzgerald EM, Jones OT (2011) Targeting of voltage-gated calcium channel alpha2delta-1 subunit to lipid rafts is independent from a GPIanchoring motif. PLoS One 6:e19802. https://doi.org/10.1371/ journal.pone.0019802

92. Rodriguez-Lopez J, Sobrino B, Amigo J, Carrera N, Brenlla J, Agra S, Paz E, Carracedo A, Paramo M, Arrojo M, Costas J (2018) Identification of putative second genetic hits in schizophrenia carriers of high-risk copy number variants and resequencing in additional samples. Eur Arch Psychiatry Clin Neurosci 268:585592. https://doi.org/10.1007/s00406-017-0799-5

93. Savalli N, Pantazis A, Sigg D, Weiss JN, Neely A, Olcese R (2016) The alpha2delta- 1 subunit remodels CaV1.2 voltage sensors and allows $\mathrm{Ca} 2+$ influx at physiological membrane potentials. J Gen Physiol 148:147-159. https://doi.org/10.1085/jgp.201611586

94. Schlegel DK, Glasauer SMK, Mateos JM, Barmettler G, Ziegler U, Neuhauss SCF (2019) A new zebrafish model for CACNA2D4-dysfunction. Invest Ophthalmol Vis Sci 60:5124 5135. https://doi.org/10.1167/iovs.19-26759

95. Schlick B, Flucher BE, Obermair GJ (2010) Voltage-activated calcium channel expression profiles in mouse brain and cultured hippocampal neurons. Neuroscience 167:786-798. https://doi. org/10.1016/j.neuroscience.2010.02.037

96. Schneider R, Hosy E, Kohl J, Klueva J, Choquet D, Thomas U, Voigt A, Heine M (2015) Mobility of calcium channels in the 
presynaptic membrane. Neuron 86:672-679. https://doi.org/10. 1016/j.neuron.2015.03.050

97. Schöpf CL, Geisler S, Stanika RI, Campiglio M, Kaufmann WA, Nimmervoll B, Schlick B, Shigemoto R, Obermair GJ (2019) Presynaptic $\alpha 2 \delta$ subunits are key organizers of glutamatergic synapses. bioRxiv 826016. https://doi.org/10.1101/826016

98. Scott MB, Kammermeier PJ (2017) CaV2 channel subtype expression in rat sympathetic neurons is selectively regulated by alpha2delta subunits. Channels (Austin) 11:555-573. https://doi. org/10.1080/19336950.2017.1356954

99. Senatore A, Colleoni S, Verderio C, Restelli E, Morini R, Condliffe SB, Bertani I, Mantovani S, Canovi M, Micotti E, Forloni G, Dolphin AC, Matteoli M, Gobbi M, Chiesa R (2012) Mutant PrP suppresses glutamatergic neurotransmission in cerebellar granule neurons by impairing membrane delivery of VGCC alpha(2)delta-1 subunit. Neuron 74:300-313. https://doi.org/10. 1016/j.neuron.2012.02.027

100. Skafidas E, Testa R, Zantomio D, Chana G, Everall IP, Pantelis C (2014) Predicting the diagnosis of autism spectrum disorder using gene pathway analysis. Mol Psychiatry 19:504-510. https://doi. org/10.1038/mp.2012.126

101. Smedler E, Bergen SE, Song J, Landen M (2019) Genes, biomarkers, and clinical features associated with the course of bipolar disorder. Eur Neuropsychopharmacol 29:1152-1160. https://doi. org/10.1016/j.euroneuro.2019.07.132

102. Smith M, Flodman PL, Gargus JJ, Simon MT, Verrell K, Haas R, Reiner GE, Naviaux R, Osann K, Spence MA, Wallace DC (2012) Mitochondrial and ion channel gene alterations in autism. Biochim Biophys Acta 1817:1796-1802. https://doi.org/10.1016/j.bbabio. 2012.04.004

103. Stahl EA, Breen G, Forstner AJ, McQuillin A, Ripke S, Trubetskoy V, Mattheisen M, Wang Y, Coleman JRI, Gaspar HA, de Leeuw CA, Steinberg S, Pavlides JMW, Trzaskowski M, Byrne EM, Pers TH, Holmans PA, Richards AL, Abbott L, Agerbo E, Akil H, Albani D, Alliey-Rodriguez N, Als TD, Anjorin A, Antilla V, Awasthi S, Badner JA, Baekvad-Hansen M, Barchas JD, Bass N, Bauer M, Belliveau R, Bergen SE, Pedersen CB, Boen E, Boks MP, Boocock J, Budde M, Bunney $\mathrm{W}$, Burmeister M, Bybjerg-Grauholm J, Byerley W, Casas M, Cerrato F, Cervantes P, Chambert K, Charney AW, Chen D, Churchhouse C, Clarke TK, Coryell W, Craig DW, Cruceanu C, Curtis D, Czerski PM, Dale AM, de Jong S, Degenhardt F, Del-Favero J, DePaulo JR, Djurovic S, Dobbyn AL, Dumont A, Elvsashagen T, Escott-Price V, Fan CC, Fischer SB, Flickinger M, Foroud TM, Forty L, Frank J, Fraser C, Freimer NB, Frisen L, Gade K, Gage D, Garnham J, Giambartolomei C, Pedersen MG, Goldstein J, Gordon SD, Gordon-Smith K, Green EK, Green MJ, Greenwood TA, Grove J, Guan W, Guzman-Parra J, Hamshere ML, Hautzinger M, Heilbronner U, Herms S, Hipolito M, Hoffmann P, Holland D, Huckins L, Jamain S, Johnson JS, Jureus A, Kandaswamy R, Karlsson R, Kennedy JL, KittelSchneider S, Knowles JA, Kogevinas M, Koller AC, Kupka R, Lavebratt C, Lawrence J, Lawson WB, Leber M, Lee PH, Levy SE, Li JZ, Liu C, Lucae S, Maaser A, MacIntyre DJ, Mahon PB, Maier W, Martinsson L, McCarroll S, McGuffin P, McInnis MG, McKay JD, Medeiros H, Medland SE, Meng F, Milani L, Montgomery GW, Morris DW, Muhleisen TW, Mullins N, Nguyen H, Nievergelt CM, Adolfsson AN, Nwulia EA, O'Donovan C, Loohuis LMO, Ori APS, Oruc L, Osby U, Perlis RH, Perry A, Pfennig A, Potash JB, Purcell SM, Regeer EJ, Reif A, Reinbold CS, Rice JP, Rivas F, Rivera M, Roussos P, Ruderfer DM, Ryu E, Sanchez-Mora C, Schatzberg AF, Scheftner WA, Schork NJ, Shannon Weickert C, Shehktman T, Shilling PD, Sigurdsson E, Slaney C, Smeland OB, Sobell JL, Soholm Hansen C, Spijker AT, St Clair D, Steffens M, Strauss JS, Streit F, Strohmaier J, Szelinger S, Thompson RC, Thorgeirsson TE,
Treutlein J, Vedder H, Wang W, Watson SJ, Weickert TW, Witt SH, Xi S, Xu W, Young AH, Zandi P, Zhang P, Zollner S, e QC, Consortium B, Adolfsson R, Agartz I, Alda M, Backlund L, Baune BT, Bellivier F, Berrettini WH, Biernacka JM, Blackwood DHR, Boehnke M, Borglum AD, Corvin A, Craddock N, Daly MJ, Dannlowski U, Esko T, Etain B, Frye M, Fullerton JM, Gershon ES, Gill M, Goes F, GrigoroiuSerbanescu M, Hauser J, Hougaard DM, Hultman CM, Jones I, Jones LA, Kahn RS, Kirov G, Landen M, Leboyer M, Lewis CM, Li QS, Lissowska J, Martin NG, Mayoral F, McElroy SL, McIntosh AM, McMahon FJ, Melle I, Metspalu A, Mitchell PB, Morken G, Mors O, Mortensen PB, Muller-Myhsok B, Myers RM, Neale BM, Nimgaonkar V, Nordentoft M, Nothen MM, O'Donovan MC, Oedegaard KJ, Owen MJ, Paciga SA, Pato C, Pato MT, Posthuma D, Ramos-Quiroga JA, Ribases M, Rietschel M, Rouleau GA, Schalling M, Schofield PR, Schulze TG, Serretti A, Smoller JW, Stefansson H, Stefansson K, Stordal E, Sullivan PF, Turecki G, Vaaler AE, Vieta E, Vincent JB, Werge T, Nurnberger JI, Wray NR, Di Florio A, Edenberg HJ, Cichon S, Ophoff RA, Scott LJ, Andreassen OA, Kelsoe J, Sklar P, Bipolar Disorder Working Group of the Psychiatric Genomics C (2019) Genome-wide association study identifies 30 loci associated with bipolar disorder. Nat Genet 51:793-803. https://doi. org/10.1038/s41588-019-0397-8

104. Stephani F, Scheuer V, Eckrich T, Blum K, Wang W, Obermair GJ, Engel J (2019) Deletion of the $\mathrm{Ca}(2+)$ channel subunit alpha2delta3 differentially affects Cav2.1 and Cav2.2 currents in cultured spiral ganglion neurons before and after the onset of hearing. Front Cell Neurosci 13:278. https://doi.org/10.3389/fncel.2019.00278

105. Striessnig J (2016) Voltage-gated calcium channels - from basic mechanisms to disease. J Physiol 594:5817-5821. https://doi.org/ 10.1113/JP272619

106. Sun W, Larson MJ, Kiyoshi CM, Annett AJ, Stalker WA, Peng J, Tedeschi A (2020) Gabapentinoid treatment promotes corticospinal plasticity and regeneration following murine spinal cord injury. $\mathrm{J}$ Clin Invest 130:345-358. https://doi.org/10.1172/JCI130391

107. Surmeier DJ (2007) Calcium, ageing, and neuronal vulnerability in Parkinson's disease. Lancet Neurol 6:933-938. https://doi.org/ 10.1016/S1474-4422(07)70246-6

108. Tedeschi A, Dupraz S, Laskowski CJ, Xue J, Ulas T, Beyer M, Schultze JL, Bradke F (2016) The calcium channel subunit alpha2delta2 suppresses axon regeneration in the adult CNS. Neuron 92:419-434. https://doi.org/10.1016/j.neuron.2016.09.026

109. Tedeschi A, Popovich PG (2019) The application of omics technologies to study axon regeneration and CNS repair. F1000Res 8 . https://doi.org/10.12688/f1000research.17084.1

110. Terauchi A, Umemori H (2012) Specific sets of intrinsic and extrinsic factors drive excitatory and inhibitory circuit formation. Neuroscientist 18:271-286. https://doi.org/10.1177/ 1073858411404228

111. Tombacz D, Maroti Z, Kalmar T, Csabai Z, Balazs Z, Takahashi S, Palkovits M, Snyder M, Boldogkoi Z (2017) High-coverage whole-exome sequencing identifies candidate genes for suicide in victims with major depressive disorder. Sci Rep 7:7106. https://doi.org/10.1038/s41598-017-06522-3

112. Tomsig JL, Creutz CE (2000) Biochemical characterization of copine: a ubiquitous $\mathrm{Ca} 2+$-dependent, phospholipid-binding protein. Biochemistry 39:16163-16175. https://doi.org/10.1021/bi0019949

113. Torres VI, Vallejo D, Inestrosa NC (2017) Emerging synaptic molecules as candidates in the etiology of neurological disorders. Neural Plast 2017:8081758. https://doi.org/10.1155/2017/8081758

114. Tuluc P, Kern G, Obermair GJ, Flucher BE (2007) Computer modeling of siRNA knockdown effects indicates an essential role of the $\mathrm{Ca} 2+$ channel alpha2delta-1 subunit in cardiac excitationcontraction coupling. Proc Natl Acad Sci U S A 104:1109111096. https://doi.org/10.1073/pnas.0700577104 
115. Valence S, Cochet E, Rougeot C, Garel C, Chantot-Bastaraud S, Lainey E, Afenjar A, Barthez MA, Bednarek N, Doummar D, Faivre L, Goizet C, Haye D, Heron B, Kemlin I, Lacombe D, Milh M, Moutard ML, Riant F, Robin S, Roubertie A, Sarda P, Toutain A, Villard L, Ville D, Billette de Villemeur T, Rodriguez D, Burglen L (2019) Exome sequencing in congenital ataxia identifies two new candidate genes and highlights a pathophysiological link between some congenital ataxias and early infantile epileptic encephalopathies. Genet Med 21:553-563. https://doi.org/ 10.1038/s41436-018-0089-2

116. Van Den Bossche MJ, Strazisar M, De Bruyne S, Bervoets C, Lenaerts AS, De Zutter S, Nordin A, Norrback KF, Goossens D, De Rijk P, Green EK, Grozeva D, Mendlewicz J, Craddock N, Sabbe BG, Adolfsson R, Souery D, Del-Favero J (2012) Identification of a CACNA2D4 deletion in late onset bipolar disorder patients and implications for the involvement of voltagedependent calcium channels in psychiatric disorders. Am J Med Genet B Neuropsychiatr Genet 159B:465-475. https://doi.org/10. 1002/ajmg.b.32053

117. van Loo KMJ, Rummel CK, Pitsch J, Muller JA, Bikbaev AF, Martinez-Chavez E, Blaess S, Dietrich D, Heine M, Becker AJ, Schoch S (2019) Calcium channel subunit alpha2delta4 is regulated by early growth response 1 and facilitates epileptogenesis. J Neurosci 39:3175-3187. https://doi.org/10.1523/JNEUROSCI. 1731-18.2019

118. Vergult S, Dheedene A, Meurs A, Faes F, Isidor B, Janssens S, Gautier A, Le Caignec C, Menten B (2015) Genomic aberrations of the CACNA2D1 gene in three patients with epilepsy and intellectual disability. Eur J Hum Genet 23:628-632. https://doi.org/ 10.1038/ejhg.2014.141

119. Voigt A, Freund R, Heck J, Missler M, Obermair GJ, Thomas U, Heine M (2016) Dynamic association of calcium channel subunits at the cellular membrane. Neurophotonics 3:041809. https://doi. org/10.1117/1.NPh.3.4.041809

120. Wakamori M, Mikala G, Mori Y (1999) Auxiliary subunits operate as a molecular switch in determining gating behaviour of the unitary N-type Ca2+ channel current in Xenopus oocytes. J Physiol 517(Pt 3):659-672. https://doi.org/10.1111/j.1469-7793. 1999.0659s.x

121. Wang T, Guo H, Xiong B, Stessman HA, Wu H, Coe BP, Turner TN, Liu Y, Zhao W, Hoekzema K, Vives L, Xia L, Tang M, Ou J, Chen B, Shen Y, Xun G, Long M, Lin J, Kronenberg ZN, Peng Y, Bai T, Li H, Ke X, Hu Z, Zhao J, Zou X, Xia K, Eichler EE (2016) De novo genic mutations among a Chinese autism spectrum disorder cohort. Nat Commun 7:13316. https://doi.org/10.1038/ ncomms 13316

122. Wang T, Jones RT, Whippen JM, Davis GW (2016) Alpha2delta3 is required for rapid transsynaptic homeostatic signaling. Cell Rep 16:2875-2888. https://doi.org/10.1016/j.celrep.2016.08.030

123. Wang Y, Fehlhaber KE, Sarria I, Cao Y, Ingram NT, GuerreroGiven D, Throesch B, Baldwin K, Kamasawa N, Ohtsuka T, Sampath AP, Martemyanov KA (2017) The auxiliary calcium channel subunit alpha2delta4 is required for axonal elaboration, synaptic transmission, and wiring of rod photoreceptors. Neuron 93:1359-1374 e1356. https://doi.org/10.1016/j.neuron.2017.02. 021

124. Whittaker CA, Hynes RO (2002) Distribution and evolution of von Willebrand/integrin A domains: widely dispersed domains with roles in cell adhesion and elsewhere. Mol Biol Cell 13: 3369-3387. https://doi.org/10.1091/mbc.e02-05-0259

125. Winham SJ, Cuellar-Barboza AB, McElroy SL, Oliveros A, Crow S, Colby CL, Choi DS, Chauhan M, Frye MA, Biernacka JM (2014) Bipolar disorder with comorbid binge eating history: a genome-wide association study implicates APOB. J Affect Disord 165:151-158. https://doi.org/10.1016/j.jad.2014.04.026
126. Wu J, Yan Z, Li Z, Qian X, Lu S, Dong M, Zhou Q, Yan N (2016) Structure of the voltage-gated calcium channel $\mathrm{Ca}(\mathrm{v}) 1.1$ at $3.6 \mathrm{~A}$ resolution. Nature 537:191-196. https://doi.org/10.1038/nature19321

127. Wycisk KA, Budde B, Feil S, Skosyrski S, Buzzi F, Neidhardt J, Glaus E, Nurnberg P, Ruether K, Berger W (2006) Structural and functional abnormalities of retinal ribbon synapses due to Cacna2d4 mutation. Invest Ophthalmol Vis Sci 47:3523-3530. https://doi.org/10.1167/iovs.06-0271

128. Wycisk KA, Zeitz C, Feil S, Wittmer M, Forster U, Neidhardt J, Wissinger B, Zrenner E, Wilke R, Kohl S, Berger W (2006) Mutation in the auxiliary calcium-channel subunit CACNA2D4 causes autosomal recessive cone dystrophy. Am J Hum Genet 79: 973-977. https://doi.org/10.1086/508944

129. Yin X, Bizon C, Tilson J, Lin Y, Gizer IR, Ehlers CL, Wilhelmsen KC (2017) Genome-wide meta-analysis identifies a novel susceptibility signal at CACNA2D3 for nicotine dependence. Am J Med Genet B Neuropsychiatr Genet 174:557-567. https://doi.org/10. 1002/ajmg.b.32540

130. Yu YP, Gong N, Kweon TD, Vo B, Luo ZD (2018) Gabapentin prevents synaptogenesis between sensory and spinal cord neurons induced by thrombospondin- 4 acting on pre-synaptic Cav alpha2 deltal subunits and involving T-type $\mathrm{Ca}(2+)$ channels. $\mathrm{Br} \mathrm{J}$ Pharmacol 175:2348-2361. https://doi.org/10.1111/bph.14149

131. Yuen RKC, Merico D, Bookman M, J LH, Thiruvahindrapuram B, Patel RV, Whitney J, Deflaux N, Bingham J, Wang Z, Pellecchia G, Buchanan JA, Walker S, Marshall CR, Uddin M, Zarrei M, Deneault E, D'Abate L, Chan AJ, Koyanagi S, Paton T, Pereira SL, Hoang N, Engchuan W, Higginbotham EJ, Ho K, Lamoureux S, Li W, MacDonald JR, Nalpathamkalam T, Sung WW, Tsoi FJ, Wei J, Xu L, Tasse AM, Kirby E, Van Etten W, Twigger S, Roberts W, Drmic I, Jilderda S, Modi BM, Kellam B, Szego M, Cytrynbaum C, Weksberg R, Zwaigenbaum L, Woodbury-Smith M, Brian J, Senman L, Iaboni A, Doyle-Thomas K, Thompson A, Chrysler C, Leef J, SavionLemieux T, Smith IM, Liu X, Nicolson R, Seifer V, Fedele A, Cook EH, Dager S, Estes A, Gallagher L, Malow BA, Parr JR, Spence SJ, Vorstman J, Frey BJ, Robinson JT, Strug LJ, Fernandez BA, Elsabbagh M, Carter MT, Hallmayer J, Knoppers BM, Anagnostou E, Szatmari P, Ring RH, Glazer D, Pletcher MT, Scherer SW (2017) Whole genome sequencing resource identifies 18 new candidate genes for autism spectrum disorder. Nat Neurosci 20:602-611. https://doi.org/10.1038/nn.4524

132. Zamponi GW (2016) Targeting voltage-gated calcium channels in neurological and psychiatric diseases. Nat Rev Drug Discov 15: 19-34. https://doi.org/10.1038/nrd.2015.5

133. Zhang FX, Gadotti VM, Souza IA, Chen L, Zamponi GW (2018) BK potassium channels suppress Cavalpha2delta subunit function to reduce inflammatory and neuropathic pain. Cell Rep 22:19561964. https://doi.org/10.1016/j.celrep.2018.01.073

134. Zhang T, Zhu L, Ni T, Liu D, Chen G, Yan Z, Lin H, Guan F, Rice JP (2018) Voltage-gated calcium channel activity and complex related genes and schizophrenia: a systematic investigation based on Han Chinese population. J Psychiatr Res 106:99-105. https:// doi.org/10.1016/j.jpsychires.2018.09.020

135. Zhao Y, Huang G, Wu J, Wu Q, Gao S, Yan Z, Lei J, Yan N (2019) Molecular basis for ligand modulation of a mammalian voltage-gated $\mathrm{Ca}(2+)$ channel. Cell 177:1495-1506 e1412. https://doi.org/10.1016/j.cell.2019.04.043

136. Zhou JJ, Li DP, Chen SR, Luo Y, Pan HL (2018) The alpha2delta-1NMDA receptor coupling is essential for corticostriatal long-term potentiation and is involved in learning and memory. J Biol Chem 293:19354-19364. https://doi.org/10.1074/jbc.RA118.003977

Publisher's note Springer Nature remains neutral with regard to jurisdictional claims in published maps and institutional affiliations. 